\begin{tabular}{|c|l|}
\hline \multicolumn{1}{|c|}{ Title } & Mechanisms of arsenic and lead release from hy drothermally altered rock \\
\hline Author(s) & Tabelin, C. B.; Igarashi, T. \\
\hline Citation & $\begin{array}{c}\text { Journal of Hazardous Materials, 169(1-3), 980-990 } \\
\text { https:/doi.org/L0.1016/.jhazmat.2009.04.049 }\end{array}$ \\
\hline Issue Date & 2009-09-30 \\
\hline Doc URL & http://hdl.handle.net/2115/39132 \\
\hline Type & article (author version) \\
\hline Additional Information & There are other files related to this item in HUSCAP. Check the above URL. \\
\hline File Information & JHM169-1-3_p980-990.pdf \\
\hline
\end{tabular}

Instructions for use 


\title{
Mechanisms of arsenic and lead release from hydrothermally altered rock
}

\author{
C.B. Tabelin* and T. Igarashi \\ Division of Field Engineering for Environment, Graduate School of Engineering, Hokkaido \\ University, Sapporo 060-8628, JAPAN \\ E-mails: carlito@trans-er.eng.hokudai.ac.jp and tosifumi@eng.hokudai.ac.jp
}

\begin{abstract}
This paper describes the effects of $\mathrm{pH}$, dissolved oxygen (DO), redox conditions, and mixing ratio of different rocks on the leaching behaviors of $\mathrm{As}$ and $\mathrm{Pb}$ from hydrothermally altered rock as well as the functional groups incorporating $\mathrm{As}$ and $\mathrm{Pb}$ in the rock. Most of $\mathrm{As}$ and $\mathrm{Pb}$ were incorporated in the residual or crystalline phase although significant amounts were also determined to be exchangeable, with carbonates and with FeMn oxides. Under oxic conditions, $\mathrm{As}$ and $\mathrm{Pb}$ showed similar leaching behaviors at similar $\mathrm{pH}$ values, a higher mobilization in the acidic and alkaline regions and a minimum at circumneutral $\mathrm{pH}$. The absence of DO restricted the oxidation of sulfide minerals that also contained significant quantities of As resulting in a lower As release under these conditions. Strongly reducing conditions favored the release of As by the reductive dissolution of FeMn oxides and prevention of carbonate precipitation while the same conditions immobilized $\mathrm{Pb}$ because of its re-precipitation under reducing conditions. In general, depending on the $\mathrm{pH}, \mathrm{DO}$, and redox conditions, the major modes of $\mathrm{As}$ and $\mathrm{Pb}$ release from these sources could be either one or more of the following mechanisms: acid dissolution, reductive dissolution, ion exchange, desorption and sulfide oxidation processes.
\end{abstract}

Keywords: Arsenic; Lead; Leaching; pH; Redox condition

\footnotetext{
*Corresponding author: Tel: +81-11-706-6311 Fax: +81-11-706-6308

email: carlito@trans-er.eng.hokudai.ac.jp
} 


\section{Introduction}

Arsenic $(\mathrm{As})$ and lead $(\mathrm{Pb})$ contamination of soil and groundwater is a serious problem encountered around the world. Both of these elements are toxic when ingested, inhaled or absorbed through the skin. Orpiment $\left(\mathrm{As}_{2} \mathrm{~S}_{3}\right)$, realgar $(\mathrm{AsS})$ and arsenopyrite $(\mathrm{FeAsS})$ are the most commonly encountered solid phases of As in the subsurface environment, and these As-bearing minerals are also concentrated in hydrothermal veins or rocks affected by hydrothermal solutions [1,2]. Hydrothermally altered rock occurs when hydrothermal solution, which is defined as the hot, watery solution that escapes from magma during the later stages of crystallization [3], invades the surrounding rock. Superheated groundwater, meteoric water or seawater in contact with active volcanic strata can also affect the surrounding rock in a fashion similar to hydrothermal solutions. This migrating hot water removes metallic ions from intrusive igneous rock and carries them upwards where they can be deposited [3]. Indeed, previous research by Tanaka et al. [4] confirmed that altered rock contained higher amounts of $\mathrm{As}, \mathrm{Pb}$, and other elements than unaltered rock.

The mobility of trace metals and metalloids such as $\mathrm{As}, \mathrm{Pb}, \mathrm{Cd}$, and $\mathrm{Zn}$ in groundwater, aquifer sediments, mine tailings and contaminated soil is largely controlled by the $\mathrm{pH}$, redox conditions, precipitation and adsorption reactions, the presence of organic matter that drives reducing conditions and the sources of As and trace metals that affect their chemical forms $[5,6,7,8,9]$. Arsenic is relatively mobile throughout the entire Eh and $\mathrm{pH}$ range while heavy metals such as $\mathrm{Pb}$ are easily precipitated as carbonates in mildly alkaline-reducing conditions and as sulfides in strongly reducing conditions $[8,10]$. There have been extensive studies of As speciation and adsorption, but very few deal with As leaching behavior from hydrothermally altered rock. A previous study by the authors showed that As mobilization 
from hydrothermally altered rock was highly $\mathrm{pH}$ dependent with higher leaching in both acidic and alkaline environments and a minimum at circumneutral $\mathrm{pH}$ [11]. The study also showed that Fe-bearing minerals strongly affected As release from hydrothermally altered rock. Al-Abed et al. [12] and Igarashi et al. [13] reported similar observations regarding the $\mathrm{pH}$ dependence of As leached from Fe-rich mineral processing waste and various rocks, respectively. The previous papers of the authors [11,13], however, used rock samples containing only As. This paper aims at extending those previous results by using a variety of rock types, changing the leaching conditions and examining coexisting constituents in order to understand the leaching mechanisms involved in the release of $\mathrm{As}$ and $\mathrm{Pb}$ from these sources.

In Japan, research efforts are now directed at the potential risk of excavated rock that is hydrothermally altered. The large contents of toxic elements such as $\mathrm{As}$ and $\mathrm{Pb}$ renders some waste rock useless as aggregate in construction and poses as an environmental hazard if disposed improperly. Landfill is the currently used disposal method; however, this is very expensive due to the large volumes of waste rock excavated and alternate methods are being explored.

For the purpose of designing an alternative method of waste rock disposal, the leaching behaviors of $\mathrm{As}$ and $\mathrm{Pb}$ from hydrothermally altered waste rock have to be elucidated. In this study, parameters such as the $\mathrm{pH}$, oxidation-reduction potential (Eh), dissolved oxygen (DO) and mixing ratios of different rocks were varied to simulate the conditions during disposal and to understand their roles during leaching. The mineral constituents and chemical compositions of the waste rock were also determined to know the quantity and major incorporating minerals of $\mathrm{As}$ and $\mathrm{Pb}$ in the waste rock and to provide insights into 
their behavior under simulated conditions. The data collected from this study will benefit in the understanding of the leaching behaviors of $\mathrm{As}$ and $\mathrm{Pb}$ from these particular sources and assist in the design of safer alternative disposal methods of this potentially hazardous waste rock.

\section{Materials and methods}

\subsection{Sample preparation}

Nine hydrothermally altered rock samples (Table 1) were obtained from tunnel projects in the island of Hokkaido, Japan. Most of the samples are altered igneous rock containing both $\mathrm{As}$ and $\mathrm{Pb}$ except for sample $\mathrm{H} 16$ that is a sedimentary rock with only As. The samples were crushed using a jaw crusher or an agate mortar and sieved using a $2 \mathrm{~mm}$ aperture screen. The fraction passing the screen was used as samples for the mineralogical and chemical analysis as well as the batch leaching and sequential extraction experiments.

\subsection{Chemical and mineralogical analyses}

The chemical analysis of the rock samples was conducted using an energy dispersive Xray fluorescence spectrometer, Xepos (Rigaku Corporation, Japan) while the minerals present in the samples were identified using an X-ray diffractometer, Multiflex (Rigaku Corporation, Japan). Tables 1 and 2 list the chemical composition and mineral constituents of the rock samples, respectively. Based on these results, samples ST5-8, ST6'-5, ST6-13, ST6-14, ST6-16 and ST7-10 containing pyrite also have higher sulfur (S) contents. All samples containing more than $1.27 \mathrm{wt} \% \mathrm{~S}$ have As contents of more than $100 \mathrm{mg} / \mathrm{kg}$, and $\mathrm{Pb}$ contents of more than $117 \mathrm{mg} / \mathrm{kg}$. The XRD analysis (Table 2) of the samples did not detect crystalline phases of As such as arsenopyrite, realgar, or orpiment, which suggests 
that the presence of As is in the interstitial, substitutional, or adsorbed forms. Galena (PbS), one of the crystalline phases of $\mathrm{Pb}$, was detected only in sample ST6-13.

\subsection{Sequential extraction procedure}

The sequential extraction procedure used in this study was modified from the method developed by Tessier et al. [14] for determining the speciation of trace metals. The organic fraction step was omitted because the rock samples did not contain appreciable amounts of organic matter. Washing the residue with 10-15 $\mathrm{ml}$ deionized water was done after each step and the mixed solution of the leachate and the water used for washing was diluted to $50 \mathrm{ml}$ for analysis. The residual fraction was determined by calculating the difference between the total $\mathrm{As}$ or $\mathrm{Pb}$ content of the sample and the total amount of extracted $\mathrm{As}$ or $\mathrm{Pb}$. Details of the sequential extraction procedure are summarized in Tables 3 and 4.

\subsection{Leaching experiments}

Batch leaching experiments were conducted under oxic, anoxic and reducing conditions. In all runs, 15 grams of sample and $150 \mathrm{ml}$ of prepared solution were mixed at $120 \mathrm{rpm}$ for 24 hours. The leaching time was fixed at 24 hours because the previous study by Igarashi et al. [13] showed that apparent equilibrium was attained approximately after 1-7 days of leaching for hydrothermally altered crushed rocks. Oxic experiments were conducted at ambient conditions while both anoxic and reducing experiments were performed inside a glove box. For the leaching experiments under reducing conditions, sodium dithionite $\left(\mathrm{Na}_{2} \mathrm{~S}_{2} \mathrm{O}_{4}\right)$ was added as a reducing agent. The dithionite solutions were always freshly prepared immediately before the experiments and the experiments were performed inside a glove box under 100\% argon (Ar) gas to prevent the decomposition of the dithionite ions. 
The $\mathrm{pH}$ of the oxic and reducing experiments was adjusted using hydrochloric acid $(\mathrm{HCl})$ or sodium hydroxide $(\mathrm{NaOH})$ solution whereas that of the anoxic experiments was controlled using four different concentrations of carbon dioxide $\left(\mathrm{CO}_{2}\right)$ gas, namely $0,1,3$, and $30 \%$ with argon gas as the remainder.

The mixed sample leaching experiments were conducted by mixing different ratios of samples with acidic $\mathrm{pH}$ when placed in deionized water and samples that had alkaline $\mathrm{pH}$ in deionized water. Samples ST6-13 (with acidic pH in deionized water) and ST6-3 (with alkaline $\mathrm{pH}$ in deionized water) were mixed in different proportions, 1:1, 1:2, 1:3, 2:1, 3:1, and $8.5: 1.5$.

All leachates were collected by filtration ( $0.45 \mu \mathrm{m}$ Millipore sterile filters), acidified and then stored at $6{ }^{0} \mathrm{C}$ prior to the chemical analysis.

\subsection{Chemical analysis}

Liquid-phase $\mathrm{As}$ and $\mathrm{Pb}$ concentrations of more than $0.1 \mathrm{mg} / \mathrm{L}$ were analyzed using an inductively coupled plasma atomic emission spectrometer (ICP-AES) (Shimadzu Corporation, Japan). Arsenic and $\mathrm{Pb}$ concentrations below $0.1 \mathrm{mg} / \mathrm{L}$ were analyzed using an ICP-AES coupled with a hydride generator and ICP-AES coupled with an ultrasonic aerosol generator, respectively. The concentrations of the other coexisting constituents in the leachate such as $\mathrm{Fe}$ and $\mathrm{Ca}$ were also quantified using ICP-AES. Since the major chemical form of sulfur in the leachate during the oxic and anoxic conditions was found to be sulfate $\left(\mathrm{SO}_{4}{ }^{2-}\right)$, ICP-AES was also used for $\mathrm{SO}_{4}{ }^{2-}$ analysis. The results of the analyses using ICP-AES had a margin of error of ca. 2-3\% while the hydride generation process utilized for lower As concentration had an uncertainty of ca. 5\%. 
Distributions of $\mathrm{As}, \mathrm{Pb}$ and the other elements on the surface of the rock samples were examined using an energy dispersive micro X-ray fluorescence spectrometer ( $\mu$ EDX-1300) (Shimadzu Corporation, Japan) to compare with the results of the leaching experiments.

\subsection{Geochemical modeling}

A geochemical modeling software, PHREEQC [15], was used to calculate the saturation indices of the precipitates/minerals of interest during the leaching process. These include hydroxides, oxides, and carbonates that affect the mobilization of both $\mathrm{As}$ and $\mathrm{Pb}$. Results of the geochemical model can give valuable insights into the liquid/solid interactions occurring during the experiments.

\section{Results and discussion}

\subsection{Sequential extraction of As and Pb}

Sequential extraction was conducted to determine the functional groups incorporating $\mathrm{As}$ and $\mathrm{Pb}$ in the rock. Figure 1 shows that most samples had $\mathrm{As}$ in the residual or crystalline form (silicates, aluminates, and sulfides) ranging from $74 \%$ to $97 \%$ except sample H16 where only $23 \%$ of As was associated with this phase. This indicates that most of the As content of the rock is relatively resistant to mobilization under commonly occurring conditions. In the igneous rock samples, significant amounts were also found incorporated with Fe-Mn oxides (1-12\%) and in the exchangeable phase (1.5-15\%). The least amount was associated with carbonates ranging from 0.1 to $2 \%$. For the sedimentary rock sample (H16), higher amounts were associated with the exchangeable phase (43\%), carbonates (3\%) and Fe-Mn oxides (31\%). However, even though the sedimentary rock sample had more As in the easily leachable phases (i.e. exchangeable, carbonates, and 
oxides), the total As content was lower than the igneous rock samples (Table 2). The total leachable fraction of the sedimentary rock sample (H16) was ca. $8.1 \mathrm{mg} / \mathrm{kg}$ while that of the igneous rock samples was higher at ca. $11-35 \mathrm{mg} / \mathrm{kg}$.

The incorporation of $\mathrm{Pb}$ with the different phases and minerals present in the rock was also evaluated using sequential extraction experiments. The results of the extraction are illustrated in Figure 2, showing that $\mathrm{Pb}$ associated with the residual or crystalline form ranges from 10 to $80 \%$. Samples ST5-7 and ST6-3, without any detectible pyrite content, had high amounts of $\mathrm{Pb}$ associated with the easily leachable phases (90\% in ST5-7 and $88 \%$ in ST6-3). Sample ST6-13 with detectible galena also had a high amount of easily leachable $\mathrm{Pb}$, about $70 \%$, while the rest of the samples that contained pyrite had less than $30 \%$ associated with these phases. Comparing the results of the sequential extraction summarized in Figures 1 and 2, it is noteworthy that although $\mathrm{As}$ and $\mathrm{Pb}$ are similarly associated in the rock (i.e. with exchangeable, carbonates, oxides and crystalline phases), $\mathrm{Pb}$ seems to have a higher affinity to carbonate minerals than As.

\subsection{Rock surface observation by $\mu$-EDX}

The residual or crystalline phase was further explored using $\mu$-EDX analysis to determine the characteristics of $\mathrm{As}$ and $\mathrm{Pb}$ incorporated in this phase. Surface maps of $\mathrm{Fe}, \mathrm{S}$, $\mathrm{Si}, \mathrm{As}$, and $\mathrm{Pb}$ for the $\mathrm{ST}$ site sample are displayed in Figure 3. These maps show that although As is finely distributed throughout the rock matrix, it is concentrated around areas where both Fe and S are located. The similar chemical characteristics of As and S suggest that As in the residual phase is incorporated in significant amounts with fine pyrite crystals, 
most probably as elements substituting $\mathrm{S}$. Similar to $\mathrm{As}, \mathrm{Pb}$ is also shown to be finely distributed throughout the rock matrix although in much smaller concentrations.

Chemical analysis of random points on the surface was also performed using $\mu$-EDX as shown in Figure 4. The test points were of $50 \mu \mathrm{m}$ diameter. The presence of $\mathrm{Pb}$ and $\mathrm{As}$ as well as cases where both elements are found in the same place (P1 and P2) are clearly evident. This implies that even in the crystalline phase, $\mathrm{As}$ and $\mathrm{Pb}$ sometimes occur together in the same crystal lattice. This could also point out that a portion of $\mathrm{Pb}$ is present as finely dispersed lead sulfide and that $\mathrm{As}$ could also substitute for $\mathrm{S}$ in $\mathrm{Pb}$-sulfide minerals. The presence of both elements together with sulfide minerals indicates that the residual or crystalline phase could also release $\mathrm{As}$ and $\mathrm{Pb}$ via sulfide oxidation.

\subsection{Effects of pH and dissolved oxygen (DO) on As and Pb leaching}

In the presence of dissolved oxygen (DO), As mobilization is represented by a "V"shaped graph with higher leaching in the acidic and alkaline regions and a minimum at circumneutral $\mathrm{pH}$ as shown in Figure 5. Previous studies on As leaching by Tabelin et al. [11] and Al-Abeid et al. [12] observed a similar behavior of As as a function of $\mathrm{pH}$. Most of the samples containing pyrite had higher amount of As leached in the alkaline region between $\mathrm{pH} 9$ and 12 at ca. 0.2 to $16 \%$ of the total As content of the rock while most of the samples without pyrite had higher leaching at the acidic $\mathrm{pH}$ between 1 and 3 of ca. 4 to $36 \%$ of the total As content of the rock.

In the acidic region, there is a strong positive correlation between As and $\mathrm{Fe}$ as well as between As and Ca concentrations in the leachate (Figure 6). Coupled with the results of the sequential extraction, this suggests that the dissolution of carbonates and Fe-Mn oxide 
phases could be the dominant mechanism of As release in this region. Published studies show that pyrite oxidation is very slow under the acidic region and would only become significant with the mediation of micro-organisms that catalyze the process [16]. The leaching experiments in this study were conducted only for 24 hours, which was too short for microbial activity to be significant. Thus, the effect of the oxidation of sulfide-bearing minerals, most notably pyrite, on As leaching is smaller compared to the influence of carbonate and oxide dissolutions.

The minimum concentrations of As observed at circumneutral $\mathrm{pH}$ could be attributed to the lower dissolution of carbonates and oxides as well as the co-precipitation and/or readsorption of dissolved As with/to Fe-oxides and Fe-oxyhydroxide precipitates. The reprecipitation of dissolved Fe was predicted by calculating the saturation indices using PHREEQC with the THERMODDEM database compiled by the French Geological Survey (BRGM Institute) as shown in Table 5 for sample ST6-13.

Under alkaline conditions, As is released mostly from pyrite due to an increased rate of oxidation, and from exchangeable/adsorbed As phases because of the increased negative charge of the mineral surfaces in the rock. Desorption/ion exchange processes were included in the major modes of As release because of the significant fractions of As (5$16 \%$ ) incorporated in the exchangeable phase. Separate leaching experiments using pure pyrite showed that the oxidation of pyrite rapidly increased in the alkaline region (Figure 7). These observations regarding an increase in pyrite oxidation with $\mathrm{pH}$ have also been reported by other authors $[17,18]$. In addition, the increased carbonate ion concentration in the alkaline region could further accelerate the oxidation process via the formation of Fecarbonate complexes $[19,20]$. These points together with the identical profiles of $\mathrm{SO}_{4}{ }^{2-}$ 
concentration of the rock samples and pure pyrite as illustrated in Figure 7 justify pyrite oxidation as a significant mechanism of As release in the alkaline region. A study by Kim et al. [21] using aquifer sediments showed the strong leaching of As in the presence of bicarbonate ions. Since no correlation between As and Fe concentrations in the leachate was observed in their study, they proposed that the sources of As in their samples were Assulfides and sulfosalts rather than arsenian pyrite. A similar leaching experiment was done in order to check the effect of bicarbonate ions on As release from hydrothermally altered rock. It is clear from Figure 8 that in this study, bicarbonate ions have a minimal effect on As leaching under both oxic and anoxic conditions. In addition, a strong correlation between As and $\mathrm{Fe}$ concentrations in the leachate was also observed. The results indicate that arsenian pyrite is one of the primary sources of As from hydrothermally altered rock especially under alkaline conditions and that pyrite oxidation is one of the primary mechanisms of mobilization involved. Oxidation of pyrite and the subsequent reprecipitation of dissolved $\mathrm{Fe}$ under alkaline conditions can be described by the following proposed reactions:

$$
\begin{aligned}
& \mathrm{FeS}_{2(\mathrm{~s})}+15 / 4 \mathrm{O}_{2(\mathrm{~g})}+5 / 2 \mathrm{H}_{2} \mathrm{O} \longrightarrow \mathrm{FeOOH}_{(\mathrm{s})}+4 \mathrm{H}^{+}+2 \mathrm{SO}_{4}{ }^{2-} \quad \text { Equation } 1 \\
& 2 \mathrm{FeS}_{2(\mathrm{~s})}+15 / 2 \mathrm{O}_{2(\mathrm{~g})}+4 \mathrm{H}_{2} \mathrm{O} \longrightarrow \mathrm{Fe}_{2} \mathrm{O}_{3(\mathrm{~s})}+8 \mathrm{H}^{+}+4 \mathrm{SO}_{4}{ }^{2-} \quad \text { Equation } 2 \\
& \mathrm{FeS}_{2(\mathrm{~s})}+15 / 4 \mathrm{O}_{2(\mathrm{~g})}+7 / 2 \mathrm{H}_{2} \mathrm{O} \longrightarrow \mathrm{Fe}(\mathrm{OH})_{3(\mathrm{~s})}+4 \mathrm{H}^{+}+2 \mathrm{SO}_{4}{ }^{2-} \text { Equation } 3
\end{aligned}
$$

The above equations were derived by considering the re-precipitation of dissolved Fe on the mineral surface and/or in the bulk solution after pyrite oxidation. Although precipitates were not quantified during the experiments, the detection of Fe-oxyhydroxides $(\mathrm{FeOOH})$ and Fe-oxide $\left(\mathrm{Fe}_{2} \mathrm{O}_{3}\right)$ on surfaces and in bulk solution of pure pyrite under alkaline conditions was reported by separate studies of Todd et al. [22] and Caldeira et al. [23], 
which supports the results of PHREEQC showing the existence of $\mathrm{FeOOH}$ and $\mathrm{Fe}_{2} \mathrm{O}_{3}$ precipitates.

Figure 9 illustrates the similarity in As and $\mathrm{Pb}$ leaching behavior with respect to $\mathrm{pH}$ in the presence of DO. Similar "V"-shaped graphs are evident, showing increasing mobilization as the acidity and alkalinity increases. All samples showed higher Pb leaching amounting to ca. 0.97 to $35 \%$ of the total $\mathrm{Pb}$ content of the rock in the acidic region from pH 2 to 4 . The similarities in the leaching behavior and functional group association (i.e. exchangeable, carbonates, Fe-Mn oxides, residual/crystalline) of $\mathrm{Pb}$ and $\mathrm{As}$ strongly indicate that the two elements are incorporated similarly in the rock and that the mechanisms governing their release are alike. As the acidity increases, more $\mathrm{Pb}$ is released via the dissolution of carbonates and oxides as well as from exchangeable/adsorbed phases. In contrast to $\mathrm{As}, \mathrm{Pb}$ desorption is more pronounced in the acidic region due to an increase in the positive charge of mineral surfaces. There is a strong positive correlation between $\mathrm{Pb}$ and $\mathrm{Fe}$ as well as between $\mathrm{Pb}$ and $\mathrm{Ca}$ concentrations in the leachate (Figure 10), which also supports dissolution of carbonates and oxides as a primary mechanism of $\mathrm{Pb}$ leaching under acidic conditions.

As the $\mathrm{pH}$ increases towards the neutral region, the solubility of both carbonates and oxides as well as the release of exchangeable $\mathrm{Pb}$ decreases, leading to a minimum concentration in the leachate. As the $\mathrm{pH}$ increases further into the alkaline region, oxidation of sulfide-minerals rapidly increases causing an increase in the amount of $\mathrm{Pb}$ in the leachate. However, under alkaline conditions, a portion of the dissolved $\mathrm{Pb}$ is also immobilized due to the re-precipitation of $\mathrm{Pb}(\mathrm{OH})_{2}, \mathrm{PbCO}_{3}$, and hydrocerrusite $\left(\mathrm{Pb}\left(\mathrm{CO}_{3}\right)_{2}(\mathrm{OH})_{2}\right)$ as can be postulated with the PHREEQC results shown in Table 5. 
Figure 11 illustrates the results of the anoxic batch leaching experiments. In the absence of $\mathrm{DO}$, the $\mathrm{pH}$ still has a strong influence on $\mathrm{As}$ and $\mathrm{Pb}$ leaching as is evident from the fact that the data in the anoxic conditions are plotted near the "V"-shaped graphs obtained in the oxic conditions (Figures 5 and 9). It also appears that without DO the pH range where the minimum leaching was observed under oxic condition shrank significantly. The figure also illustrates that $\mathrm{Pb}$ leaching behavior was different from that of As under anoxic conditions in that slightly higher concentrations of $\mathrm{Pb}$ in the leachate were observed under anoxic conditions than under oxic conditions. The higher partial pressure of $\mathrm{CO}_{2}$ used to vary the $\mathrm{pH}$ during the anoxic experiments might have an effect on the increased dissolution rate of carbonate minerals or formation of carbonate complexes as is evident from a significant increase in the alkalinity of the leachate that corresponds to $\mathrm{Pb}$ mobilization. The former deduction is consistent with the study of Plummer et al. [24] showing that calcite dissolution rate increases as the partial pressure of $\mathrm{CO}_{2}$ increases especially in the $\mathrm{pH}$ range of 3.5 to 6.5 . These results suggest that the increase in the concentrations of carbonate species enhances the release of $\mathrm{Pb}$ more than that of As. The higher affinity of $\mathrm{Pb}$ with carbonates could be a reason for this discrepancy. However, the results of the anoxic leaching experiments were not enough to fully explain the mechanisms of As and $\mathrm{Pb}$ mobilization throughout the entire $\mathrm{pH}$ range under anoxic conditions and additional work has to be done on this part. None the less, the results give insights into the effect of $\mathrm{O}_{2}$ and $\mathrm{CO}_{2}$ on $\mathrm{As}$ and $\mathrm{Pb}$ leaching from these sources.

\subsection{Effect of sample mixing on As and Pb leaching}

The effect of sample mixing on As and Pb leaching was elucidated using samples ST63 and ST6-13 under oxic conditions. The results of the leaching experiments are 
summarized in Figure 12. An increase in the quantity of ST6-13 in the mixture corresponded to a decrease in the $\mathrm{pH}$ from 8.2 for $100 \%$ ST6-3 to 3.99 for $100 \%$ ST6-13 and the amount of $\mathrm{As}$ and $\mathrm{Pb}$ leached varied with the mixing ratio of the samples. Lower As and $\mathrm{Pb}$ concentrations were measured in the leachate of the mixture close to $\mathrm{pH} 7(85 \%$ ST6-13 and 15\% ST6-3). Although this amount of As and Pb leached was greater than pure ST6-3, it was lower than the quantity released with ST6-13 only. The results indicate that the mixing of waste rock during disposal can affect $\mathrm{As}$ and $\mathrm{Pb}$ leaching because it can cause significant changes in the $\mathrm{pH}$ of the system. If the degree of mixing of waste rock can be controlled during disposal, simple mixing can be utilized to reduce the leaching of both As and $\mathrm{Pb}$ from these sources.

\subsection{Effect of redox conditions on As and Pb leaching}

Figure 13 illustrates the results of leaching experiments with the addition of varying concentrations of the reducing agent $\left(\mathrm{Na}_{2} \mathrm{~S}_{2} \mathrm{O}_{4}\right)$. The redox potential of the system was effectively lowered but the addition also caused a slight change in the $\mathrm{pH}$ due to the strong buffering effect of $\mathrm{Na}_{2} \mathrm{~S}_{2} \mathrm{O}_{4}$. An increase in the concentration of $\mathrm{Na}_{2} \mathrm{~S}_{2} \mathrm{O}_{4}$ caused the $\mathrm{pH}$ to increase or decrease depending on the sample and would tend to stabilize at around $\mathrm{pH} 6$. The addition of $\mathrm{Na}_{2} \mathrm{~S}_{2} \mathrm{O}_{4}$ also increased the dissolution of carbonates especially in the samples with detectible calcite by decreasing the $\mathrm{pH}$ of the system as shown in Figure 14. A dramatic $\mathrm{Ca}$ concentration increase (ca. 10 times) was observed in sample H16 (with detectible calcite) after the addition of $0.1 \mathrm{M}$ of the reducing agent while sample ST6-14 (without detectible calcite) did not have any significant increase. 
A comparison of the $\mathrm{Ca}$ concentration of samples with detectible calcite under oxidizing conditions with that under reducing conditions illustrates the strong $\mathrm{pH}$ dependence of carbonate dissolution (Figure 15). This figure also shows that the dissolution of carbonates was affected both by the $\mathrm{pH}$ and redox potential (Eh) of the system. By comparing the samples with and without calcite, at $\mathrm{pH}$ less than 8 , the dissolution of carbonates in the samples with calcite under both oxic and reducing conditions were identical even if the redox potential (Eh) difference was large. However, higher Ca concentrations under reducing conditions were observed above $\mathrm{pH} 8$ for both samples containing calcite. In order to provide insights into the cause of this difference in $\mathrm{Ca}$ concentration above $\mathrm{pH} 8$, equilibrium constants and possible chemical reactions were calculated and modeled using the RXN program of Geochemist's Workbench ${ }^{\circledR}$ (Table 6). The results indicate that the equilibrium constant $(\log \mathrm{K})$ of $\mathrm{CaCO}_{3}$ is greater than both calcium hydroxide $\left(\mathrm{CaOH}^{+}\right)$and bicarbonate $\left(\mathrm{CaHCO}_{3}{ }^{+}\right)$complexes under both oxic (in the presence of $\mathrm{OH}^{-}$and $\mathrm{HCO}_{3}{ }^{-}$) and reducing conditions (in the presence of $\mathrm{S}_{2} \mathrm{O}_{4}{ }^{2-}$ and $\mathrm{S}^{2-}$ ), which suggests that calcium complexes are less stable compared to $\mathrm{CaCO}_{3}$ under both conditions. The higher Ca concentration observed in Figure 15 under reducing conditions above $\mathrm{pH} 8$ could be attributed to the lesser degree of Ca precipitation (lower log $\mathrm{K}$ ) either as the mineral calcite or as $\mathrm{CaCO}_{3}$ precipitates in the presence of $\mathrm{S}_{2} \mathrm{O}_{4}{ }^{2-}$ and $\mathrm{S}^{2-}$ (Table 6). The Ca concentration profile as a function of $\mathrm{pH}$ for samples without detectible calcite (ST6'-5 and ST6-13) were also highly $\mathrm{pH}$ dependent (Figure 15) but had higher Ca concentration at acidic and circumneutral $\mathrm{pH}(\mathrm{pH}$ less than 8) under reducing conditions than in oxic conditions. This could be attributed to more reactive carbonates in the samples without detectable calcite (ST6'-5 and ST6-13) than the crystalline carbonates (calcite) 
present in the samples with detectible calcite (H16 and ST6-3) and could explain the concentration discrepancy in the two conditions discussed. Figure 13 also shows that under reducing conditions the amount of As mobilized from the rock was greater than the amount released under atmospheric conditions (oxic conditions). Although oxidation of sulfidebearing minerals was effectively hindered, the higher amount of As mobilized under these conditions could be attributed to the reductive dissolution of iron oxides. This corresponds to a considerable increase in Fe concentration in the leachate as shown in Figure 16. It is also speculated that the presence of carbonates other than calcite, e.g., $\mathrm{PbCO}_{3}$ and $\mathrm{FeCO}_{3}$, in the samples is highly possible but is too low to be detected by XRD. These "other" carbonates are also important because in contrast to calcite, carbonates and oxides of redoxsensitive metals, e.g., Fe and Mn, as well as those metals that form insoluble sulfides under reducing conditions, e.g., $\mathrm{Pb}, \mathrm{Zn}, \mathrm{Cd}$ and $\mathrm{Mo}$, undergo increased dissolution under reducing conditions that can result in the release of its associated As [25,26,27]. Oxides of redoxsensitive metals undergo reductive dissolution via the direct reduction of the oxide surface by reducing organic ligands or reducing metal complexes that weaken the bonds between reduced $\mathrm{Fe}$ and $\mathrm{O}^{2-}$ in the crystal lattice (reduction of the Madelung energy) $[28,29,30]$. On the other hand, carbonates and oxides of metals that form insoluble sulfides, such as $\mathrm{Fe}, \mathrm{Pb}$, $\mathrm{Cd}$ and $\mathrm{Zn}$, dissolve under reducing conditions to supply the metal ions needed for sulfide precipitation according to Brennan and Lindsay [8]. Although not quantified, there might be thioarsenates and thioarsenites in the leachate under reducing conditions. These As species were reported to dominate in strongly reducing environments and in the presence of dissolved sulfide [31,32,33]. Stauder et al. [31] and Rochette et al. [32] reported that As precipitated as amorphous orpiment $\left(\mathrm{As}_{2} \mathrm{~S}_{3}\right)$ and metallic As under strongly reducing 
conditions especially when the As:S ratio was high $(>1: 20)$. The high concentration of the dithionite solution $(0.1 \mathrm{M})$ used in this study could also seem to induce the precipitation of As, maybe as amorphous orpiments $\left(\mathrm{As}_{2} \mathrm{~S}_{3}\right)$ or metallic As. This precipitation can be observed as a plateau in the "V"-shaped graph of As concentrations in the leachate with $\mathrm{pH}$ specially in the acidic region shown in Figure 17. Calculations of the saturation indices using PHREEQC summarized in Table 7 suggest that under alkaline and reducing conditions, the low $\mathrm{Fe}$ concentration in the leachate is due to the re-precipitation of dissolved $\mathrm{Fe}$ as oxides and hydroxides. Pyrite is also known to precipitate under acidic and strongly reducing conditions in sulfidic solutions [8]. The precipitation of $\mathrm{Fe}$ as $\mathrm{FeS}_{2}$ or amorphous $\mathrm{FeS}_{2}$ is illustrated in Figure 16 as a portion of the curve under reducing conditions that is almost parallel to the $\mathrm{pH}$ axis. On the other hand, $\mathrm{Pb}$ mobilization changed in the opposite direction since the amount of $\mathrm{Pb}$ leached significantly decreased under strongly reducing conditions as illustrated in Figure 13. To understand the behavior of $\mathrm{Pb}$ under strongly reducing conditions, the pe $+\mathrm{pH}$ parameter was calculated and are listed in Table 8. The pe $+\mathrm{pH}$ parameter was introduced by Lindsay [34] as a redox parameter to predict the dissolution and precipitation of metal sulfides in reduced environments. Brennan and Lindsay [8] calculated that if the pe $+\mathrm{pH}$ parameter was less than $4.40, \mathrm{PbS}$ would precipitate. Because the calculated pe $+\mathrm{pH}$ values were much less than $4.40, \mathrm{~Pb}$ concentration in the leachate was low because it precipitated as $\mathrm{PbS}$ in the solution.

The $\mathrm{pH}$ was also varied under reducing conditions by adding $\mathrm{HCl}$ or $\mathrm{NaOH}$ solution to the leachant. The results are illustrated in Figure 17. The leaching of As with respect to $\mathrm{pH}$ was also described by "V"-shaped graphs with higher leaching in the acidic and alkaline 
regions and a minimum at circumneutral $\mathrm{pH}$ range. However, $\mathrm{Pb}$ mobilization showed no $\mathrm{pH}$ dependence under reducing conditions, which could be attributed to the lower mobility of $\mathrm{Pb}$ than that of As under these conditions.

Comparing the three different conditions that are encountered in actual environments, oxic, anoxic, and reducing conditions, As leaching was lower under anoxic conditions than in the other two conditions as shown in Figure 18. This is primarily because under anoxic conditions, oxidation of sulfide-bearing minerals is minimal. In addition, the redox potential was not sufficiently low for reductive dissolution of oxide-bearing minerals to be significant. In all cases, however, the influence of the $\mathrm{pH}$ was identical in that an increase in As leaching was achieved at higher and lower $\mathrm{pH}$ and that a minimum was attained at near neutral $\mathrm{pH}$. On the other hand, the $\mathrm{pH}$ dependence of $\mathrm{Pb}$ was more pronounced under oxic conditions and lower mobilization under reducing conditions was observed because the oxidation of sulfide minerals was hindered and the re-precipitation of dissolved $\mathrm{Pb}$ as $\mathrm{PbS}$ was expected to be more dominant. It is also noteworthy that at circumneutral $\mathrm{pH}$ under reducing conditions the amount of $\mathrm{Pb}$ released was higher than under oxic conditions. This increase could be attributed to the enhanced reductive dissolution of oxide-bearing minerals which could result in the release of its associated $\mathrm{Pb}$ content. Under mildly reducing conditions as can be expected in an anoxic environment, dissolved $\mathrm{Pb}$ tends to precipitate as $\mathrm{PbCO}_{3}$ at $\mathrm{pH}$ above 5 [8]. The higher $\mathrm{Pb}$ concentration under anoxic condition in Figure 16 could be attributed to the inability of $\mathrm{PbCO}_{3}$ to precipitate in the acidic region while $\mathrm{PbS}$ under reducing conditions precipitates even if the solution is acidic. 


\section{Conclusions}

This study was conducted to elucidate the leaching behaviors of $\mathrm{As}$ and $\mathrm{Pb}$ under different conditions encountered in the field so as to provide insights to assist in the proper disposal of the hydrothermally altered waste rock and to minimize the release of As and $\mathrm{Pb}$ that are both toxic to human health. The findings of the study are summarized as follows:

1. Arsenic and $\mathrm{Pb}$ were associated in different functional groups in the rock, as exchangeable, with carbonates, with Fe-Mn oxides, and in residual/crystalline phase. In the residual phase, a portion of the $\mathrm{As}$ and $\mathrm{Pb}$ was detected with sulfide minerals most likely with pyrite.

2. The leaching of As was highly $\mathrm{pH}$ dependent, with higher mobilization in the acidic and alkaline regions and with a minimum at circumneutral $\mathrm{pH}$ under both oxidizing and reducing conditions. Leaching was also higher under strongly reducing conditions than under oxic conditions because of the enhanced reductive dissolution of Fe-Mn oxides.

3. Lead leaching under oxidizing conditions also followed a "V" shaped curve similar to As. Under strongly reducing conditions, the mobilization of $\mathrm{Pb}$ was not significantly increased because of its re-precipitation as $\mathrm{PbS}$ in the leachate.

4. The major mechanisms of $\mathrm{As}$ and $\mathrm{Pb}$ mobilization from hydrothermally altered rock are acid dissolution, reductive dissolution, ion exchange/desorption and sulfide oxidation processes with the dominant mechanism/s being dependent on the $\mathrm{pH}$, the presence of DO, and redox conditions. 
Based on the results of this study, the parameters that primarily need to be controlled during disposal of the rock are the $\mathrm{pH}$, redox potential, and DO. To minimize leaching of both $\mathrm{As}$ and $\mathrm{Pb}$, the $\mathrm{pH}$ must be maintained in the circumneutral region. To minimize pyrite oxidation and reductive dissolution, the redox potential should be maintained at mildly oxidizing or mildly reducing conditions and attention should be paid to the removal of DO.

\section{Acknowledgement}

The authors wish to thank Mitsubishi Materials Corporation for providing the hydrothermally altered rock samples and the Okumuragumi Environmental Fund for the financial support of this research. The inputs of the anonymous reviewers were also greatly appreciated.

\section{References}

[1] J.N. Moore, W.H. Ficklin, C. Johns, Partitioning of arsenic and metals in reducing sediments, Environ. Sci. Technol. 22 (1988) 432-437.

[2] J.M. Brannon, W.H. Patrick, Fixation, transformation and mobilization of arsenic in sediments, Environ. Sci. Technol. 21 (1987) 450-459.

[3] E.J. Tarbuck, F.K. Lutgens, Earth: An Introduction to Physical Geology, $7^{\text {th }}$ ed., Prentice Hall, New Jersey, 2002.

[4] T. Tanaka, Distribution of arsenic in the natural environment with emphasis on rocks and soils, Applied Organometallic Chemistry 2(4) (1988) 283-295.

[5] S.C. Peters, J.D. Blum, The source and transport of arsenic in a bedrock aquifer, New Hampshire, USA, Applied Geochemistry 18 (2003) 1773-1787.

[6] K.S. Savage, T.N. Tingle, P.A. O’Day, G.A. Waychunas, D.K. Bird, Arsenic speciation in pyrite and secondary weathering phases, Mother Lode Gold District, Tuolumne County, California, Applied Geochemistry 15 (2000) 1219-1244.

[7] P.A. O'Day, D. Vlassopoulos, R. Root, N. Rivera, The influence of sulfur and iron on dissolved arsenic concentrations in the shallow subsurface under changing redox conditions, Proceedings of the National Academy of Sciences 101 [38] (2004) 1370313708.

[8] E.W. Brennan, W.L. Lindsay, The role of pyrite in controlling metal ion activities in highly reduced soils, Geochim. Cosmochim. Acta 60 [19] (1996) 3609-3618. 
[9] A.L. Foster, G.E. Brown, T.N. Tingle, G.A. Parks, Quantitative arsenic speciation in mine tailings using X-ray absorption spectroscopy, American Mineralogist 83 (1998) 553-568.

[10] P.L. Smedley, D.G. Kinniburg, A review of the source, behavior and distribution of arsenic in natural waters, Applied Geochemistry 17 (2002) 517-568.

[11] C.B. Tabelin, T. Igarashi, K. Asakura, Effect of $\mathrm{pH}$ on the mobilization of arsenic from hydrothermally altered rocks, In: Proceedings of the Water Down Under 2008 Incorporating $31^{\text {st }}$ Hydrology and Water Resources Symposium and the $4{ }^{\text {th }}$ International Conference on Water Resources and Environment Research (2008), Adelaide, Australia, 2789-2797.

[12] S.R. Al-Abed, G. Jegadeesan, J. Purandare, D. Allen, Arsenic release from iron rich mineral processing waste: Influence of $\mathrm{pH}$ and redox potential, Chemosphere 66 (2006) 775-782.

[13] T. Igarashi, H. Imagawa, H. Uchiyama, K. Asakura, Leaching behavior of arsenic from various rocks by controlling geochemical conditions, Minerals Engineering 21 (2008) 191-199.

[14] A. Tessier, G.C. Campbell, M. Bisson, Sequential extraction procedure for the speciation of particulate trace metals, Analytical Chemistry 51 (1979) 844-850.

[15] D.L. Parkhurst, C.A.J. Appelo, User's guide to PHREEQC (Version 2) - A computer program for speciation, batch-reactions, one-dimensional transport, and inverse geochemical calculations, U.S. Geological Survey, Denver, Colorado, 1999.

[16] C.A.J. Appelo, D. Postma, Geochemistry, groundwater and pollution, second ed., A.A. Balkena Publishers, London, 2005.

[17] V.P. Evangelou, Pyrite oxidation and its control, CRC Press, New York, 1995.

[18] N.D. Janetski, S.I. Woodburn, R. Woods, An electrochemical investigation of pyrite flotation and depression, Int. J. Miner. Process. 4 (1977) 227-239.

[19] R.V. Nicholson, R.W. Gillham, E.J. Reardon, Pyrite oxidation in carbonate-buffered solution: 1. Experimental kinetics, Geochim. Cosmochim. Acta 52 (1988), 1077-1085.

[20] V.P. Evangelou, A.K. Seta, A. Holt, Potential role of bicarbonate during pyrite oxidation, Environ. Sci. Technol. 32 (1998), 2084-2091.

[21] M.J. Kim, J. Nriagu, S. Haack, Carbonate ions and arsenic dissolution in groundwater, Environ. Sci. Technol. 34 (2000) 3094-3100.

[22] E.C. Todd, D.M. Sherman, J.A. Purton, Surface oxidation of pyrite under ambient atmospheric and aqueous $(\mathrm{pH}=2$ to 10) conditions: Electronic structure and mineralogy from X-ray absorption spectroscopy, Geochim. Cosmochim. Acta 67(5) (2003), 881-893.

[23] C.L. Caldeira, V.S.T. Ciminelli, A. Dias, K. Osseo-Asare, Pyrite oxidation in alkaline solution: Nature of the product layer, Int. J. Miner. Process. 72 (2003), 373-386. 
[24] L.N. Plummer, T.M.L. Wigley, D.L. Parkhurst, The kinetics of calcite dissolution in $\mathrm{CO}_{2}$-water at $5^{0}$ to $60^{\circ} \mathrm{C}$ and 0.0 to $1.0 \mathrm{~atm} \mathrm{CO}_{2}$, American Journal of Science 278 (1978) 179-216.

[25] E.T. Brown, L.L. Callonnec, C.R. German, Geochemical cycling of redox-sensitive metals in sediments from Lake Malawi: A diagnostic paleotracer for episodic changes in mixing depth, Geochim. Cosmochim. Acta 64(20) (2000) 3515-3523.

[26] J. Crusius, S. Calvert, T. Pedersen, D. Sage, Rhenium and molybdenum enrichments in sediments as indicators of oxic, suboxic and sulfidic conditions of deposition, Earth Planet. Sci. Lett. 145 (1996) 65-78.

[27] Y. Rosenthal, P. Lam, E.A. Boyle, J. Thomson, Authigenic cadmium enrichments in suboxic sediments: Precipitation and post-depositional mobility, Earth Planet. Sci. Lett. 132 (1987) 99-111.

[28] S. Banwart, S. Davies, W. Stumm, The role of oxalate in accelerating the reductive dissolution of hematite $\left(\alpha-\mathrm{Fe}_{2} \mathrm{O}_{3}\right)$ by ascorbate, Colloids Surf. 39 (1989) 303-309.

[29] M. Segal, R.M. Sellers, Reactions of solid iron (III) oxides with aqueous reducing agents, J. Chem. Soc. Chem. Commun. 21 (1980) 991-993.

[30] N. Valverde, C. Wagner, Considerations on the kinetics and mechanism of the dissolution of metal oxides in acidic solution, Ber. Bunsenges. Phys. Chem. 80 (1976) 330-340.

[31] S. Stauder, B. Raue, F. Sacher, Thioarsenates in sulfidic waters, Environ. Sci. Technol. 39 (2005) 5933-5939.

[32] E.A. Rochette, B.C. Bostick, G. Li, S. Fendorf, Kinetics of arsenate reduction by dissolved sulfide, Environ. Sci. Technol. 34 (2000) 4714-4720.

[33] R.T. Wilkin, D. Wallscaläger, R.G. Ford, Speciation of arsenic in sulfidic waters, Geochem. Trans. 4 (1) (2003) 1-7.

[34] W.L. Lindsay, Chemical equilibria in soils, Wiley, New York, 1979. 


\section{FIGURE CAPTIONS}

FIGURE 1 Amount of As extracted using sequential extraction

FIGURE 2 Amount of $\mathrm{Pb}$ extracted using sequential extraction

FIGURE 3 Surface maps of $\mathrm{Si}, \mathrm{Fe}, \mathrm{S}, \mathrm{As}$, and $\mathrm{Pb}$ using $\mu$-EDX

FIGURE 4 Peaks of $\mathrm{As}$ and $\mathrm{Pb}$ using $\mu$-EDX at randomly selected points: $\mathrm{P} 1(-), \mathrm{P} 2(-)$, P3 (-), P4 (-), P5 (-), P6 (-) and P7 (-)

FIGURE 5 As concentration in the leachate as a function of $\mathrm{pH}$ under oxic conditions:

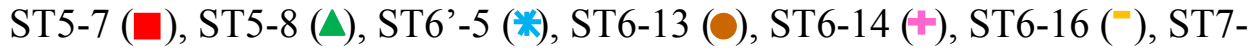
$10(\diamond)$

FIGURE 6 Relationships between $\mathrm{Fe}$ and $\mathrm{As}$ and between $\mathrm{Ca}$ and $\mathrm{As}$ in the leachate under oxic conditions: ST5-7 ( $\square)$, ST5-8 (४), ST6-3 (*), ST6’-5 (*), ST6-13 (๑), ST6-14 (*), ST6-16 (-), ST7-10 (•)

FIGURE 7 Sulfate concentrations in the leachate as a function of $\mathrm{pH}$ for pure pyrite and for samples with pyrite

FIGURE 8 Effect of $\mathrm{NaHCO}_{3}$ addition on the concentration of As in the leachate under oxic and anoxic conditions

FIGURE $9 \mathrm{~Pb}$ concentration in the leachate as a function of $\mathrm{pH}$ under oxic conditions: ST5-7 (घ), ST5-8 (४), ST6-3 (*), ST6’-5 (*), ST6-13 (๑), ST6-14 (+), ST6$16(-)$

FIGURE 10 Relationships between $\mathrm{Fe}$ and $\mathrm{Pb}$ and between $\mathrm{Ca}$ and $\mathrm{Pb}$ in the leachate under oxic conditions: ST5-7 ( $\square)$, ST5-8 (४), ST6-3 (*), ST6'-5 (*), ST6-13 $(+)$, ST6-14 (๑), ST6-16 (-)

FIGURE 11 (a) As concentration vs $\mathrm{pH}$ under oxic and anoxic conditions, (b) $\mathrm{Pb}$ concentration vs $\mathrm{pH}$ under oxic and anoxic conditions, (c) $\mathrm{SO}_{4}{ }^{2-}$ concentration vs $\mathrm{pH}$ under oxic and anoxic conditions, (d) Alkalinity vs $\mathrm{pH}$ under oxic and anoxic conditions: ST6-3 Oxic (*), ST6-3 Anoxic (*), ST613 Oxic (๑), ST6-13 Anoxic (๑), ST6-14 Oxic (+), ST6-14 Oxic (+)

FIGURE 12 The effect of sample mixing on the $\mathrm{pH}$ and concentrations of $\mathrm{As}$ and $\mathrm{Pb}$ in the leachate under oxic conditions 
FIGURE 13 Effect of $\mathrm{Na}_{2} \mathrm{~S}_{2} \mathrm{O}_{4}$ addition on the $\mathrm{pH}$, Eh and concentrations of $\mathrm{As}$ and $\mathrm{Pb}$ in the leachate

FIGURE 14 Effect of $\mathrm{Na}_{2} \mathrm{~S}_{2} \mathrm{O}_{4}$ addition on the concentration of $\mathrm{Ca}$ in the leachate

FIGURE 15 Comparison of the concentration of $\mathrm{Ca}$ in the leachate between oxic and reducing conditions: Samples without detectible calcite (a), samples with detectible calcite $(b)$

FIGURE 16 Comparison of the concentrations of $\mathrm{Fe}$ in the leachate between oxic and reducing conditions

FIGURE 17 As and $\mathrm{Pb}$ concentrations in the leachate under reducing conditions as a function of $\mathrm{pH}$

FIGURE 18 Comparison of $\mathrm{As}$ and $\mathrm{Pb}$ leaching under oxic, anoxic and reducing conditions: ST6-13 (a), ST6-14 (b) 


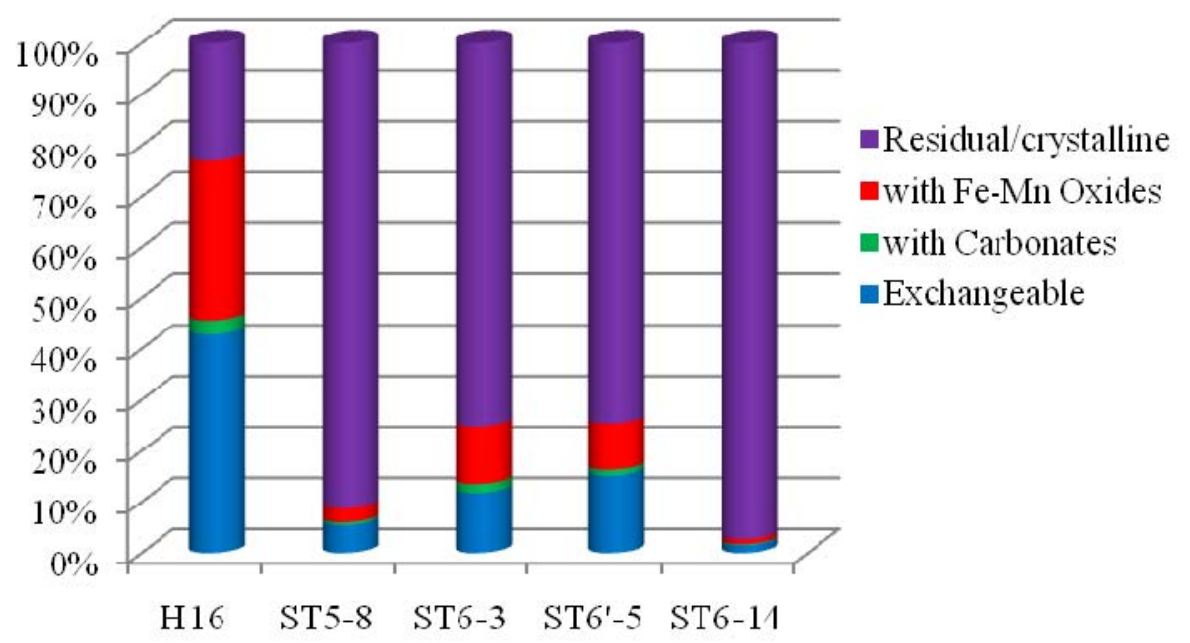

Figure 1 (colored)

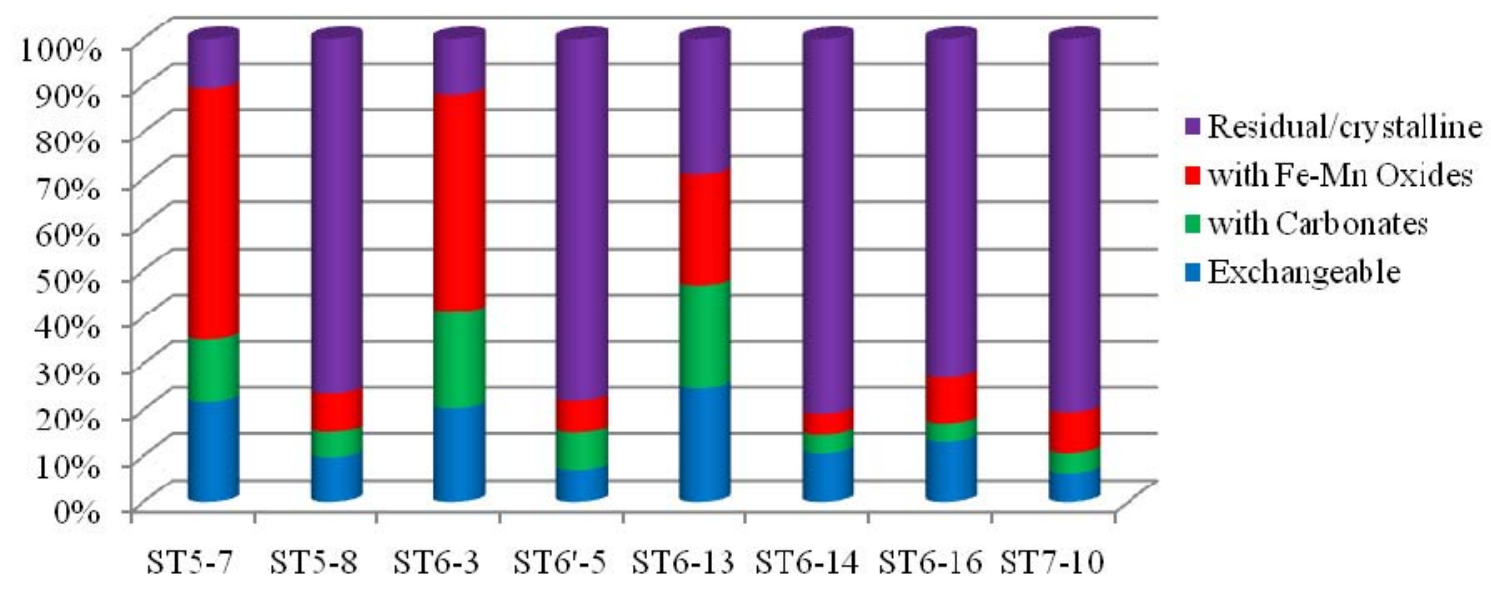

Figure 2 (colored) 

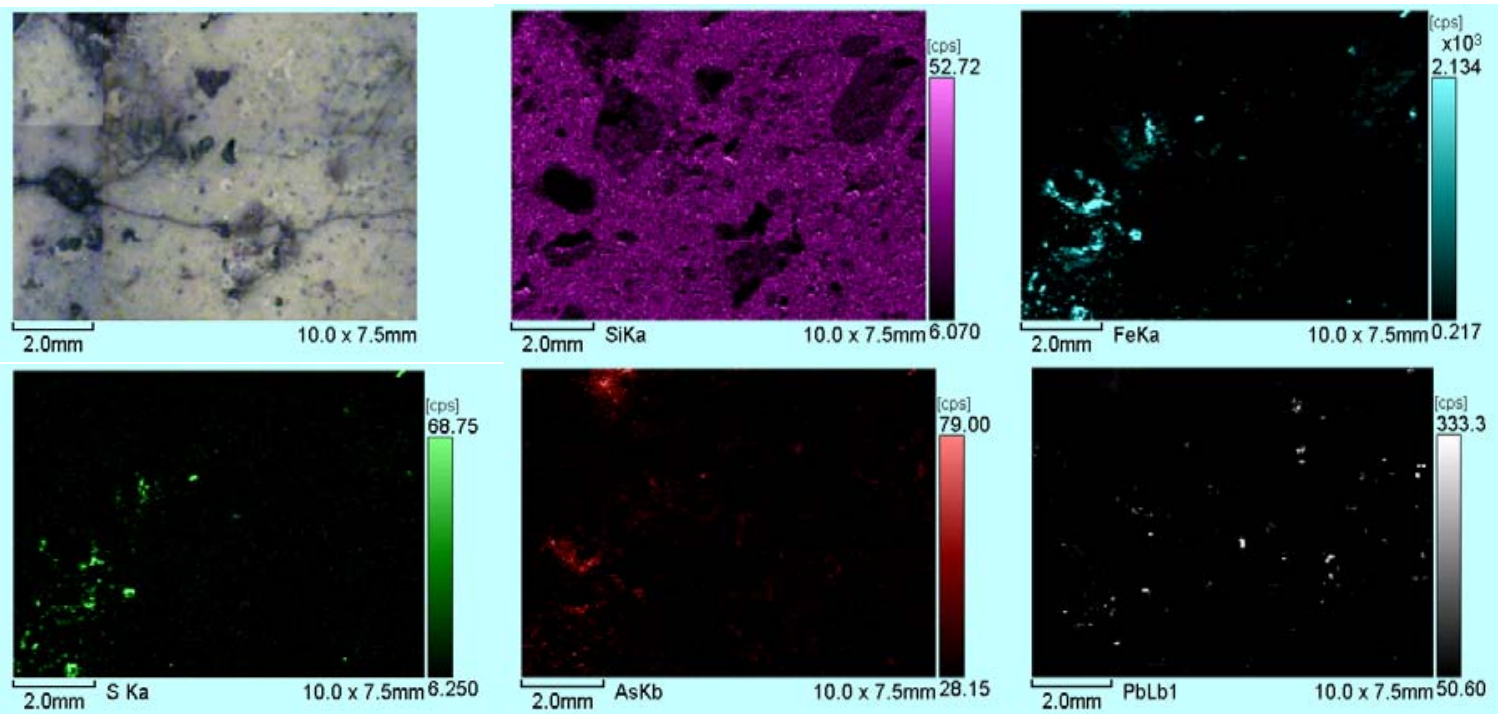

Figure 3 (colored)
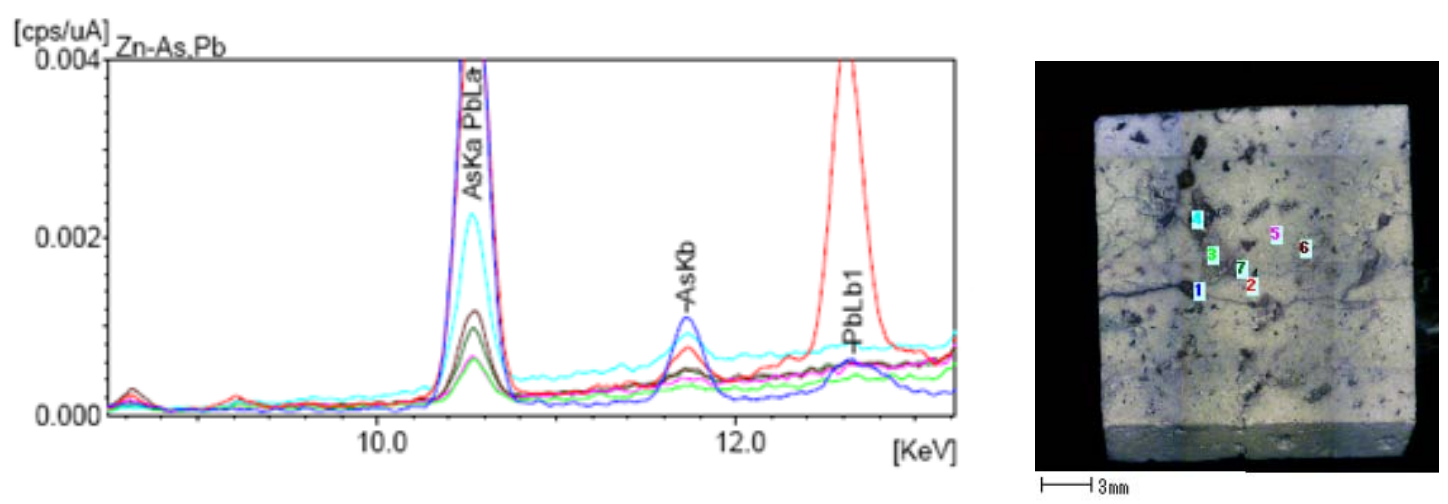

Figure 4 (colored) 


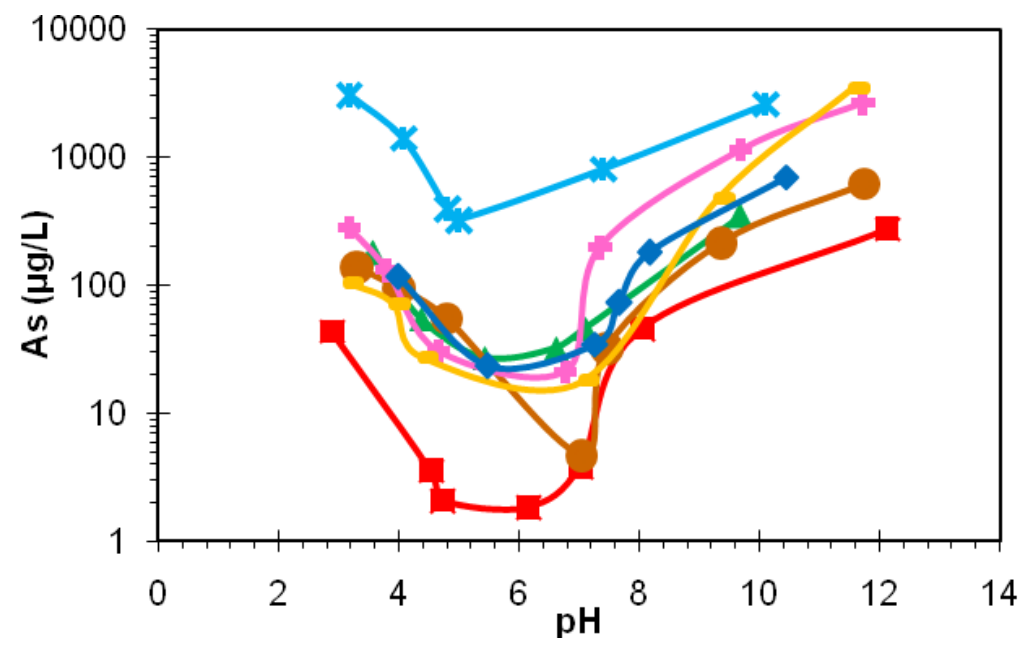

Figure 5
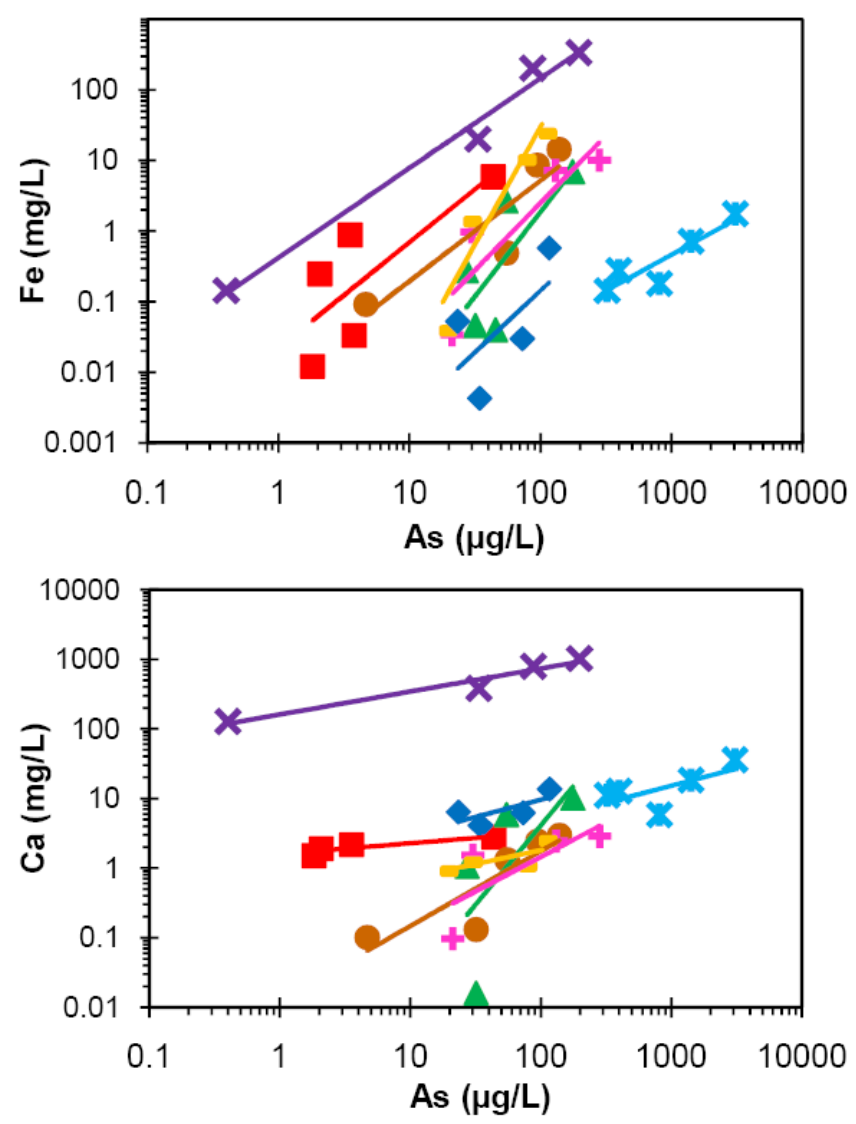

Figure 6 

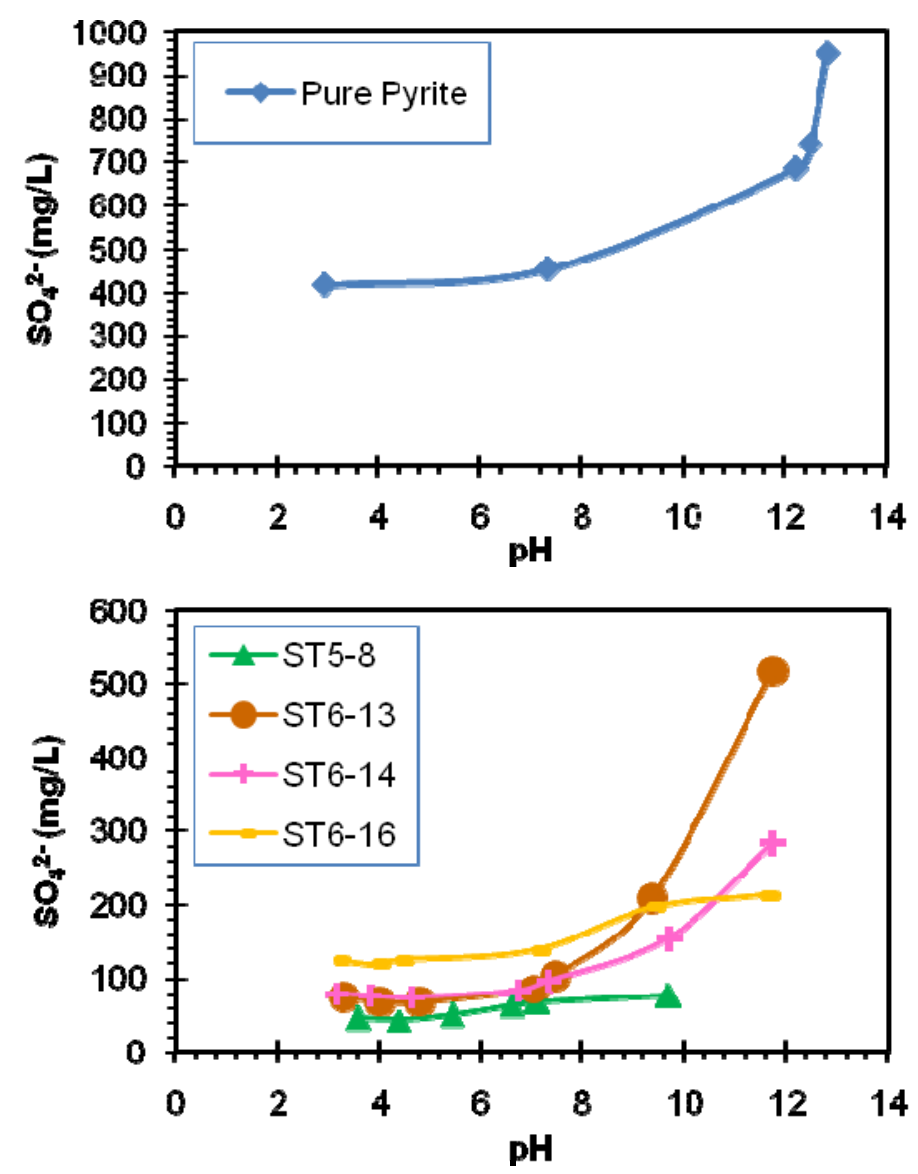

Figure 7

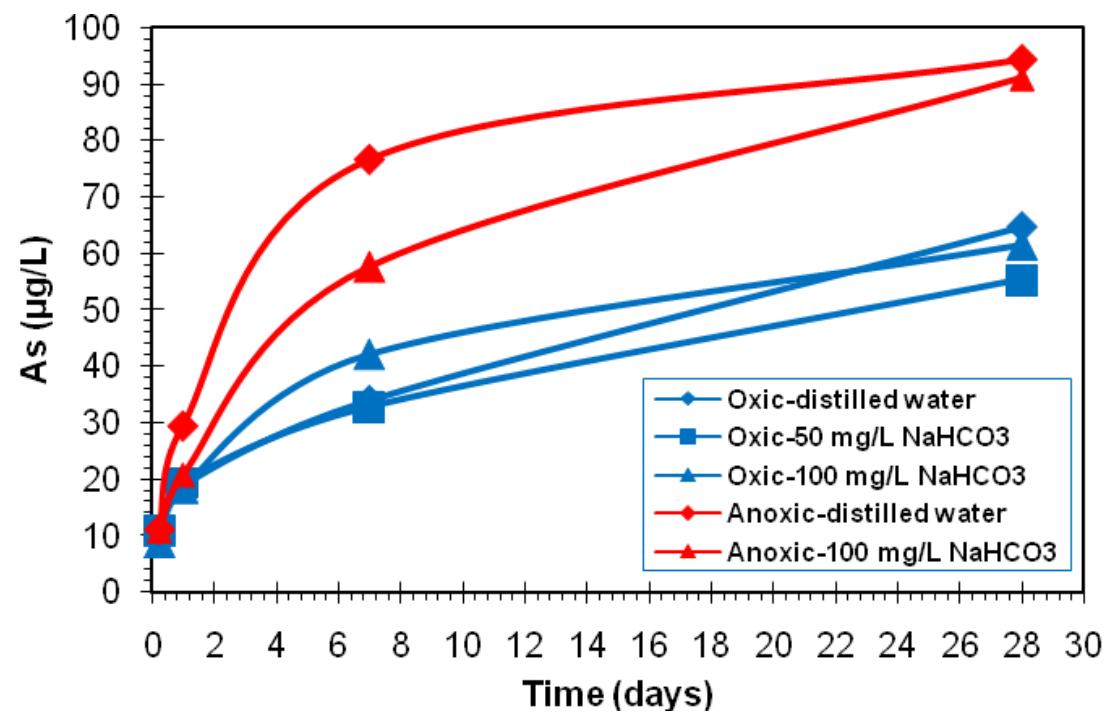

Figure 8 (Colored) 


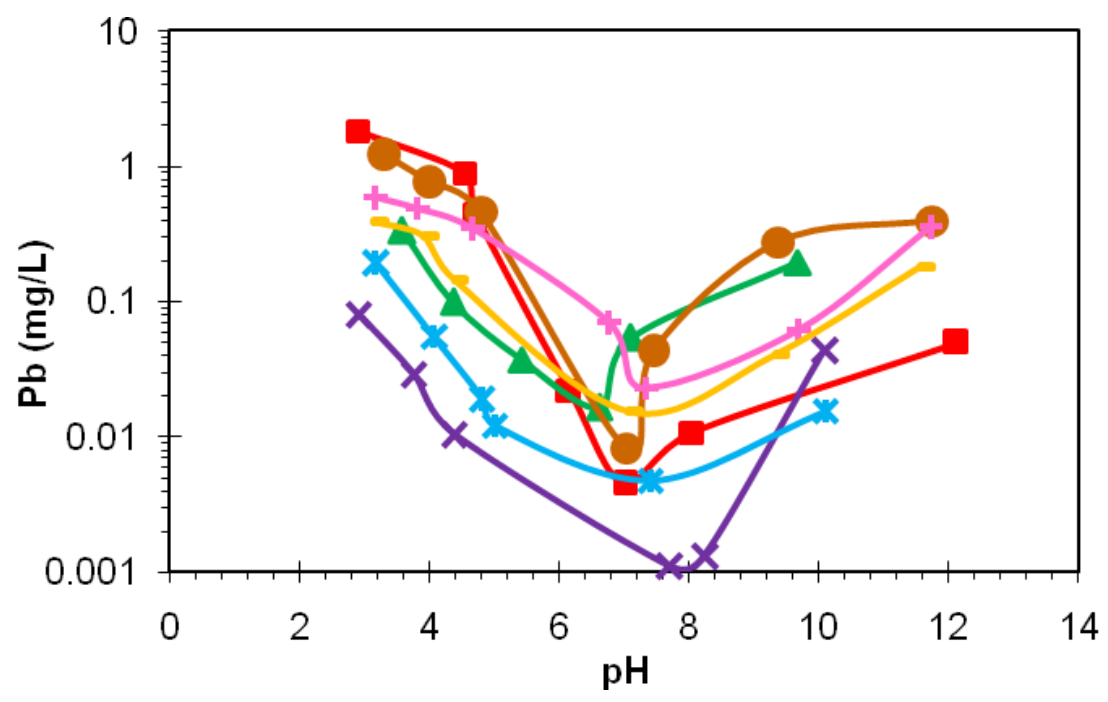

Figure 9
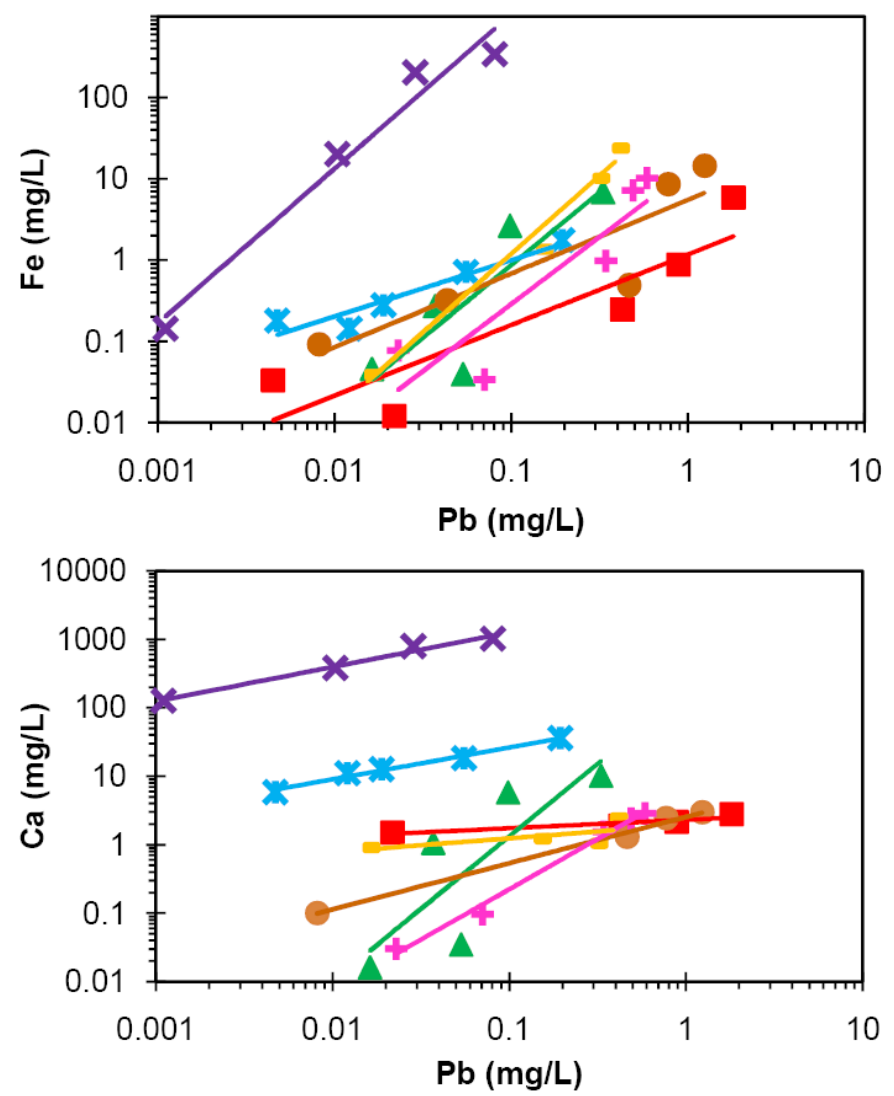

Figure 10 

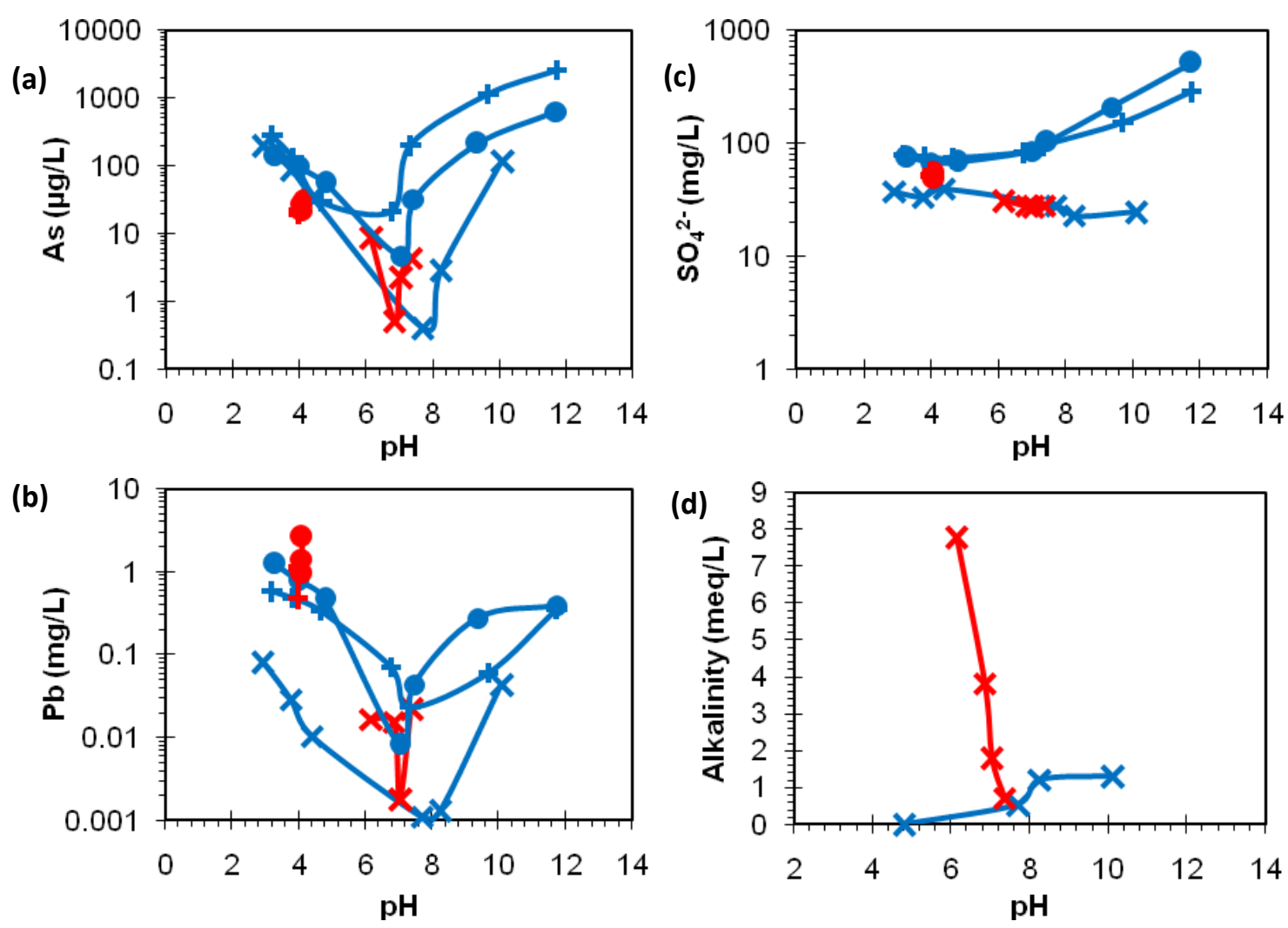

Figure 11 (colored) 

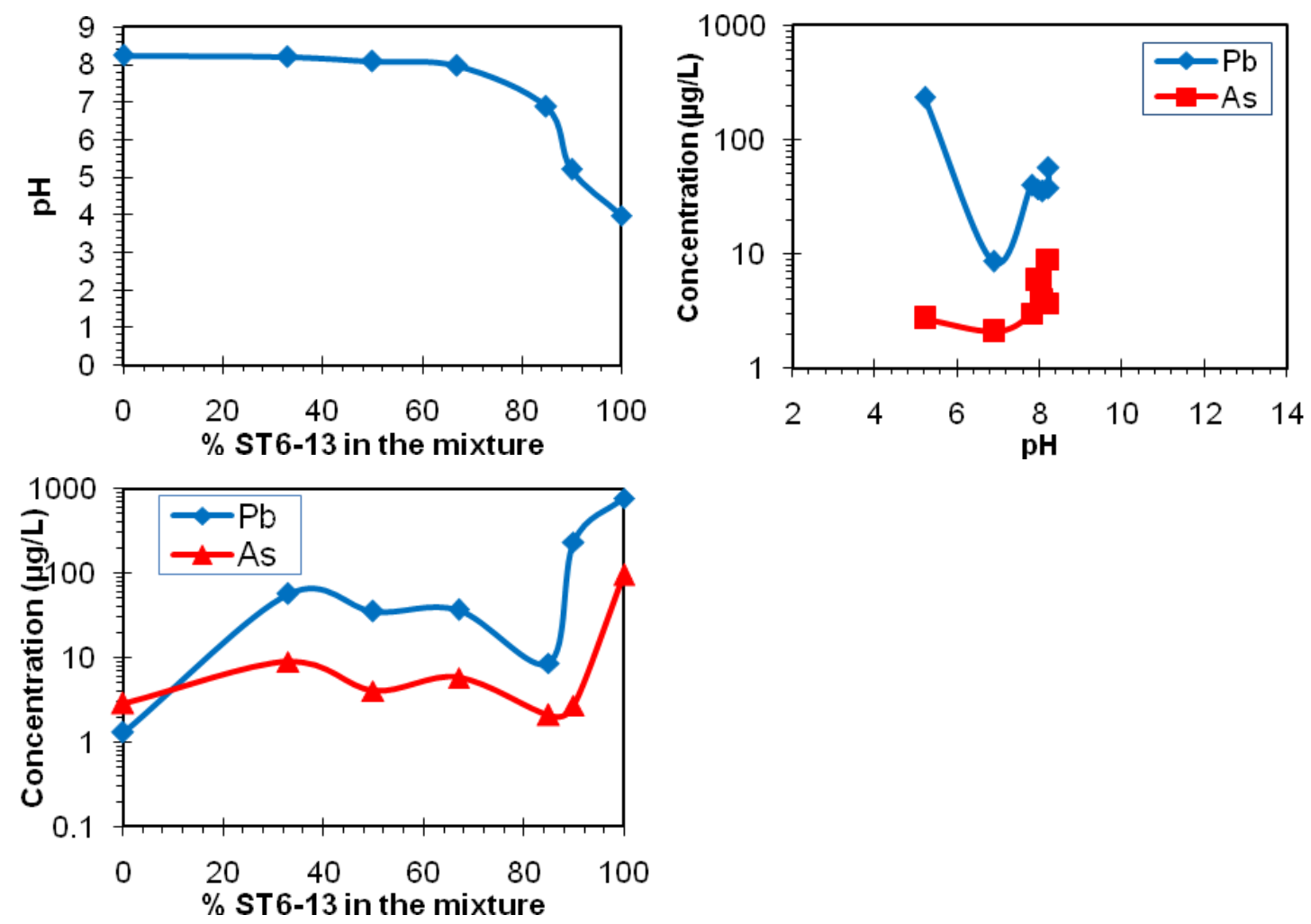

Figure 12 

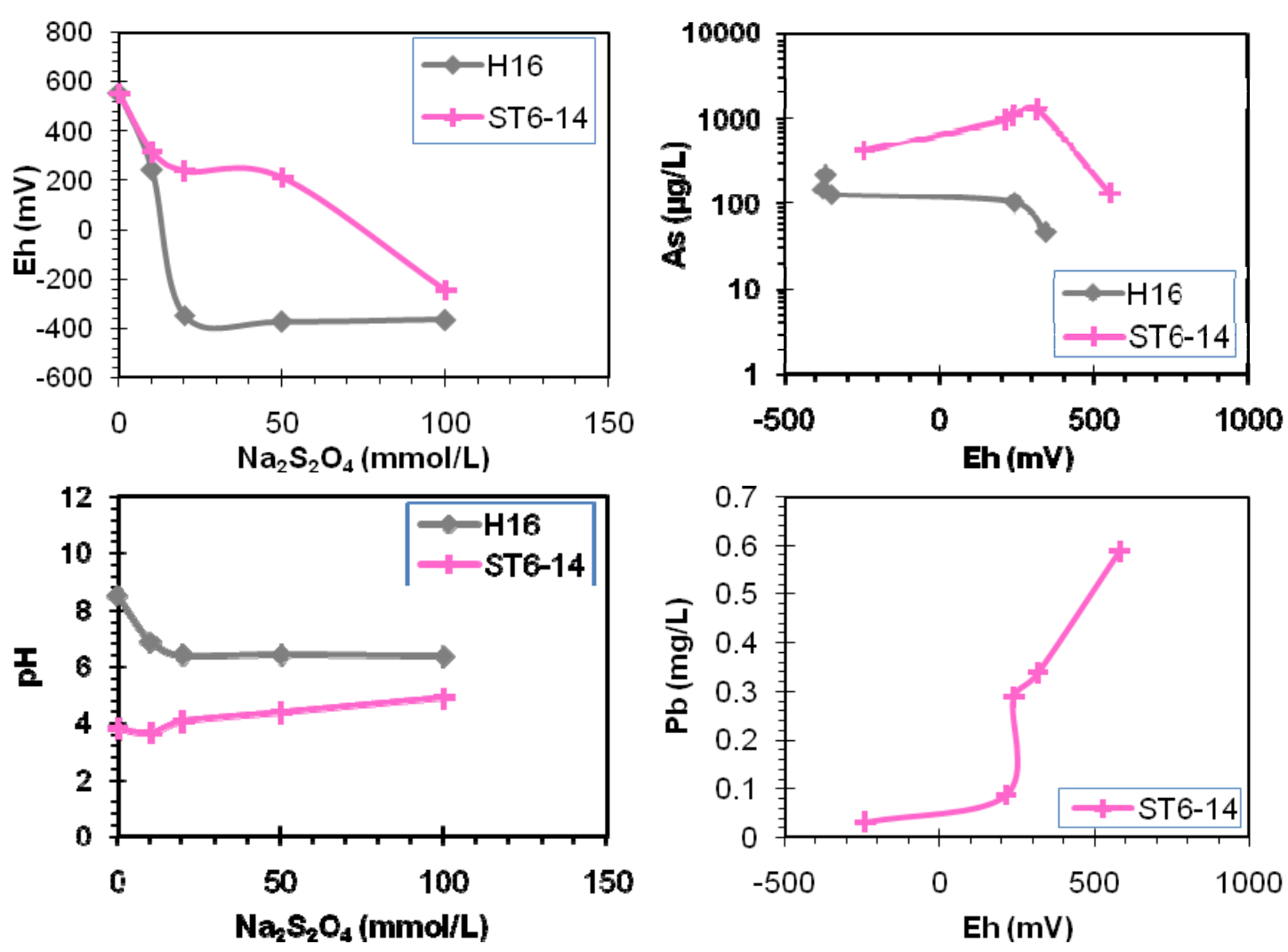

Figure 13

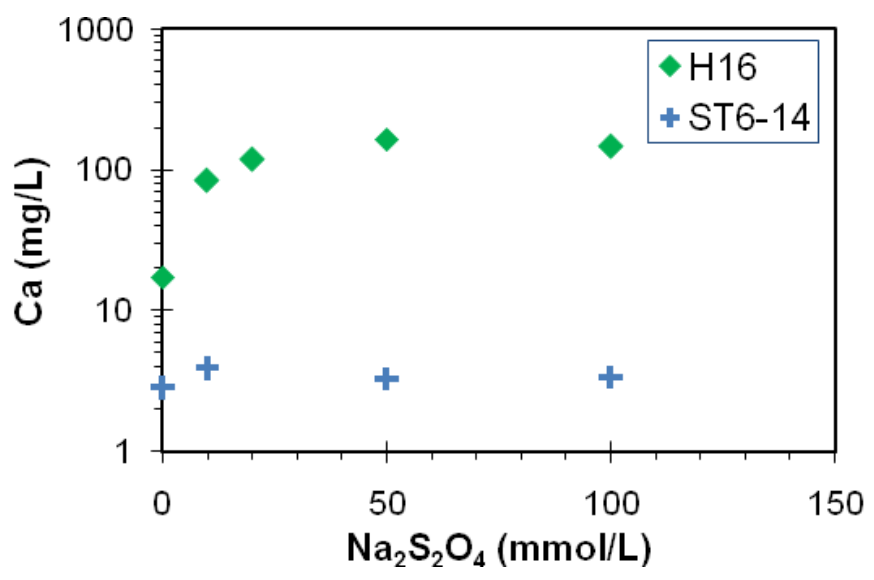

Figure 14 

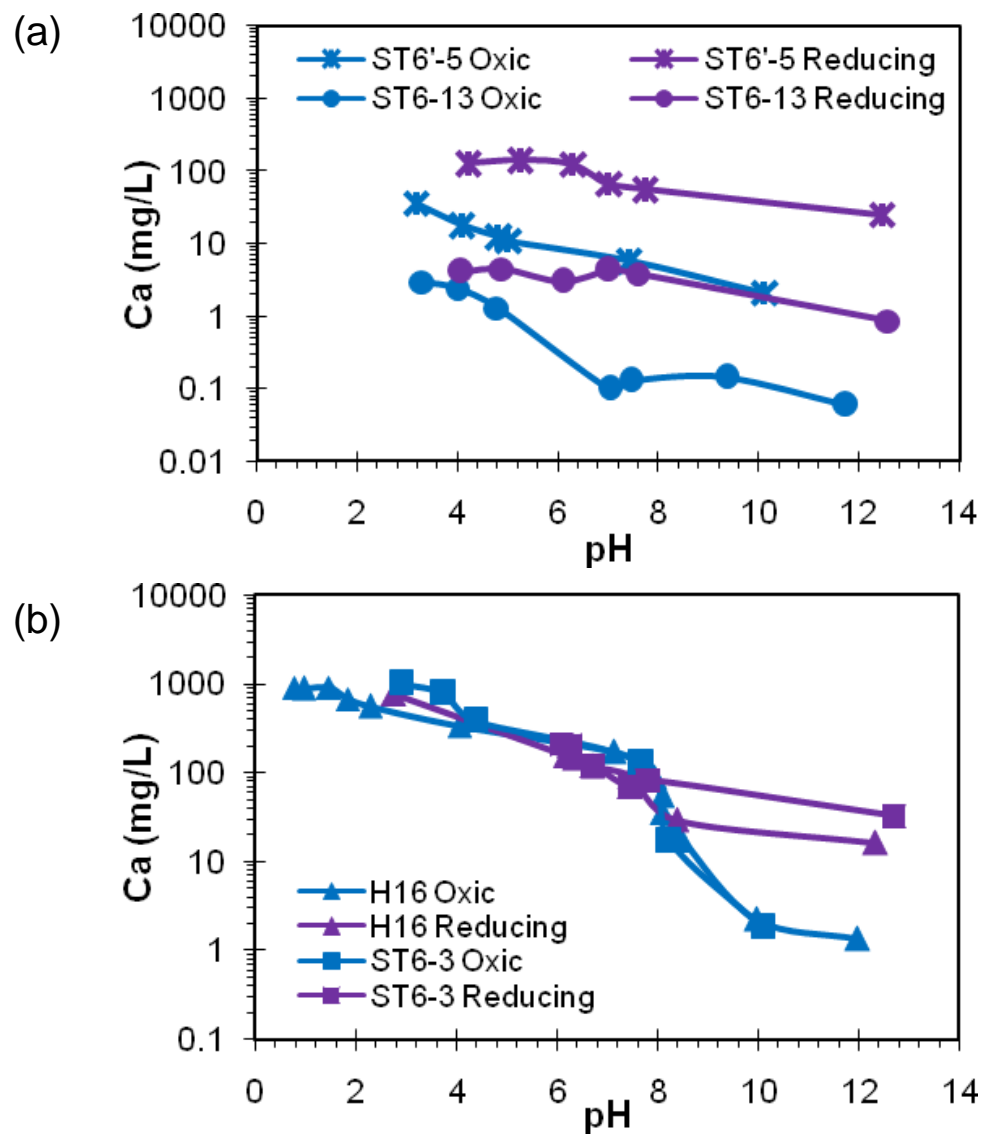

Figure 15 (Colored)

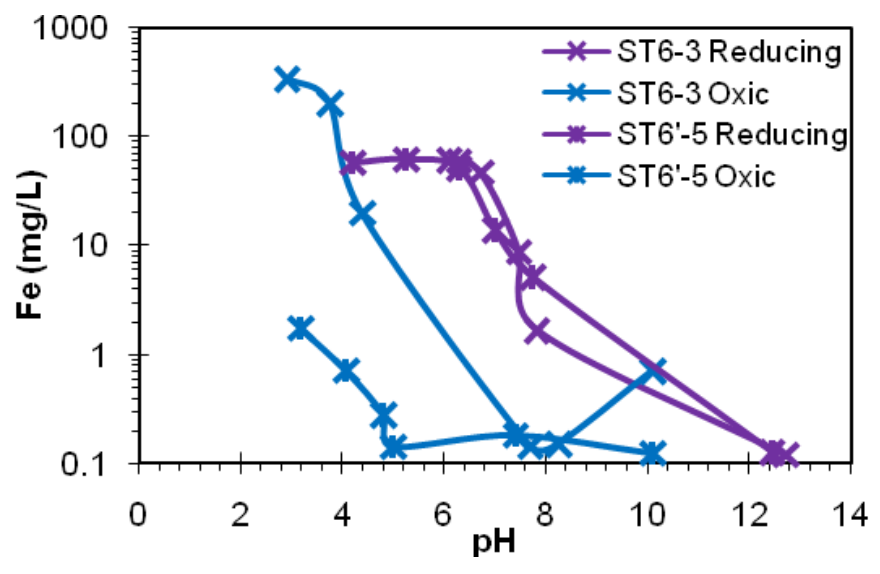

Figure 16 (Colored) 

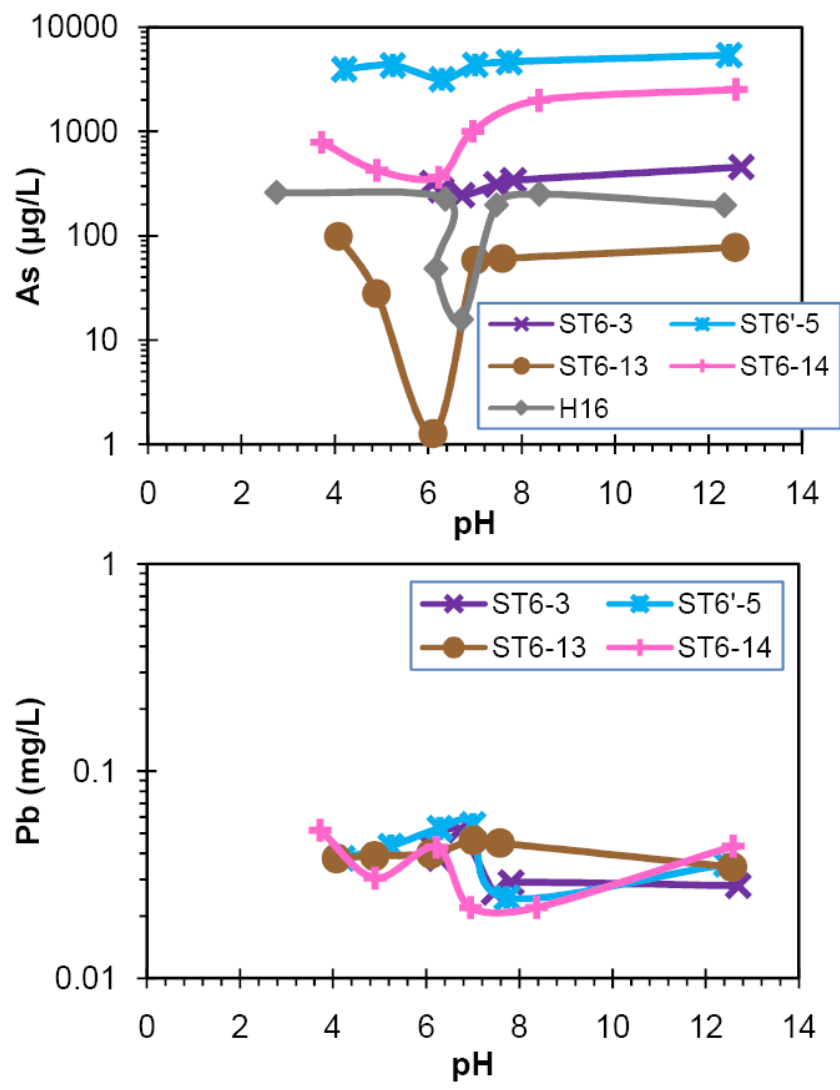

Figure 17 

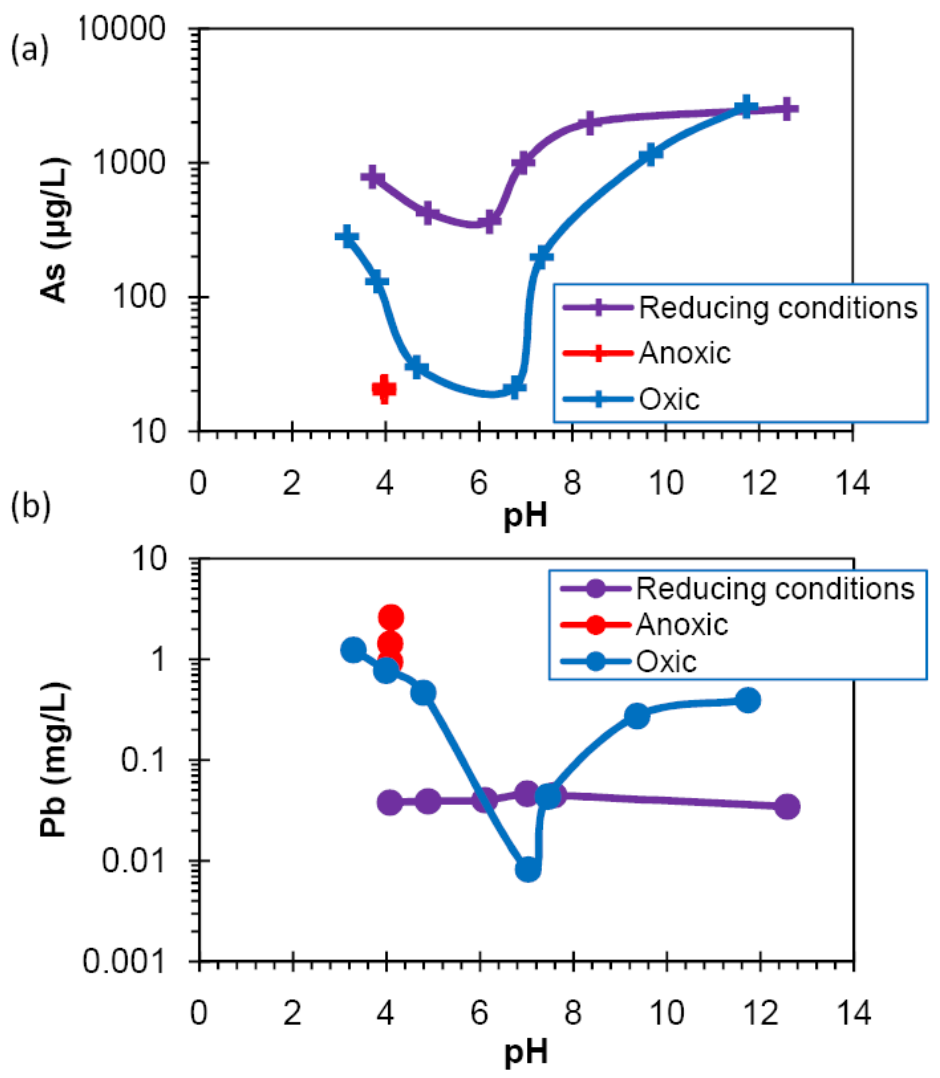

Figure 18 (Colored) 
Table 1. Chemical compositions of rock samples used

\begin{tabular}{|c|c|c|c|c|c|c|c|c|c|c|c|c|c|}
\hline Sample & $\begin{array}{c}\mathrm{SiO}_{2} \\
\text { (wt\%) }\end{array}$ & $\begin{array}{c}\mathrm{TiO}_{2} \\
\text { (wt\%) }\end{array}$ & $\begin{array}{l}\mathrm{Al}_{2} \mathrm{O}_{3} \\
\text { (wt\%) }\end{array}$ & $\begin{array}{l}\mathrm{Fe}_{2} \mathrm{O}_{3} \\
\text { (wt\%) }\end{array}$ & $\begin{array}{l}\mathrm{MnO} \\
\text { (wt\%) }\end{array}$ & $\begin{array}{l}\mathrm{MgO} \\
\text { (wt\%) }\end{array}$ & $\begin{array}{c}\mathrm{CaO} \\
\text { (wt\%) }\end{array}$ & $\begin{array}{l}\mathrm{Na}_{2} \mathrm{O} \\
(\mathrm{wt} \%)\end{array}$ & $\begin{array}{c}\mathrm{K}_{2} \mathrm{O} \\
\text { (wt\%) }\end{array}$ & $\begin{array}{c}\mathrm{P}_{2} \mathrm{O}_{5} \\
\text { (wt\%) }\end{array}$ & $\begin{array}{c}\mathrm{S} \\
\text { (wt\%) }\end{array}$ & $\underset{(\mathrm{mg} / \mathrm{kg})}{\mathrm{Pb}}$ & $\underset{(\mathrm{mg} / \mathrm{kg})}{\mathrm{As}}$ \\
\hline H16 & 43 & 0.41 & 12.1 & 5.43 & 0.1 & 2.85 & 1.59 & 0.5 & 3.02 & 0.04 & 0.27 & & 10.5 \\
\hline ST5-7 & 78.39 & 0.55 & 18.63 & 1.24 & 0.007 & 0.05 & 0.04 & 0.23 & 0.08 & 0.02 & 0.558 & 52 & 67 \\
\hline ST5-8 & 72.94 & 0.58 & 21.52 & 5.68 & 0.009 & 0.2 & 0.06 & 0.26 & 3.38 & 0.03 & 2.09 & 214 & 264 \\
\hline ST6-3 & 56.55 & 0.56 & 14.93 & 5.58 & 0.26 & 3.08 & 4.89 & 0.22 & 5.14 & 0.03 & 0.175 & 17 & 46 \\
\hline ST6'-5 & 74.8 & 0.57 & 15.07 & 4.067 & 0.033 & 0.94 & 0.25 & 0.24 & 5.34 & 0.003 & 2.28 & 199 & 346 \\
\hline ST6-13 & 80.66 & 0.28 & 17.18 & 3.75 & 0.01 & 0.06 & 0.005 & 0.26 & 1.57 & 0.05 & 2.68 & 222 & 100 \\
\hline ST6-14 & 77.6 & 0.47 & 13.46 & 2.85 & 0.06 & 0.06 & 0.03 & 0.24 & 1.37 & 0.06 & 1.97 & 329 & 1280 \\
\hline ST6-16 & 82.22 & 0.48 & 13.21 & 3.17 & 0.01 & 0.05 & 0.04 & 0.24 & 0.26 & 0.04 & 1.99 & 130 & 224 \\
\hline ST7-10 & 80.36 & 0.44 & 14.14 & 2.4 & 0.01 & 0.05 & 0.16 & 0.23 & 2.12 & 0.07 & 1.27 & 117 & 345 \\
\hline
\end{tabular}

Table 2. Constituent minerals in the rock samples used

\begin{tabular}{ll}
\hline Sample & Identified minerals \\
\hline H16 & quartz, feldspar, muscovite, chlorite, calcite, kaolinite \\
ST5-7 & quartz, feldspar, muscovite, chlorite, montmorillonite \\
ST5-8 & quartz, pyrite, kaolinite \\
ST6-3 & quartz, feldspar, chlorite, calcite \\
ST6'-5 & quartz, pyrite, muscovite, marcasite \\
ST6-13 & quartz, pyrite, kaolinite, galena \\
ST6-14 & quartz, pyrite, kaolinite \\
ST6-16 & quartz, pyrite, kaolinite \\
ST7-10 & quartz, pyrite, kaolinite \\
\hline
\end{tabular}

Table 3. Sequential extraction for arsenic speciation

\begin{tabular}{llcccccc}
\hline Step & \multicolumn{1}{c}{ Extractant } & $\mathrm{pH}$ & $\begin{array}{c}\text { Liquid } \\
\text { to solid } \\
\text { ratio } \\
(\mathrm{ml} / \mathrm{g})\end{array}$ & $\begin{array}{c}\text { Temperature } \\
\left({ }^{0} \mathrm{C}\right)\end{array}$ & $\begin{array}{c}\text { Duration } \\
(\mathrm{h})\end{array}$ & $\begin{array}{c}\text { Mixing } \\
\text { speed } \\
(\mathrm{rpm})\end{array}$ & $\begin{array}{c}\text { Extracted } \\
\text { phase }\end{array}$ \\
\hline Step 1 & $\begin{array}{l}1 \mathrm{M} \mathrm{NaH}_{2} \mathrm{PO}_{4} \\
\text { Step 2 }\end{array}$ & 5 & $20 / 1$ & 25 & 1 & 120 & Exchangeable \\
Step 3 & $\begin{array}{l}\text { 0.04M NH } \mathrm{MH}_{2} \mathrm{OH} . \mathrm{OCO} \\
\text { in 25\% acetic acid }\end{array}$ & 5 & $20 / 1$ & 25 & 5 & 120 & Carbonates \\
Step 4 & - & $\begin{array}{c}20 / 1 \\
\text { Calculated }\end{array}$ & 50 & 5 & 120 & $\begin{array}{l}\text { Fe-Mn oxides } \\
\text { Residual }\end{array}$ \\
\hline
\end{tabular}


Table 4. Sequential extraction for lead speciation

\begin{tabular}{|c|c|c|c|c|c|c|c|}
\hline Step & Extractant & $\mathrm{pH}$ & $\begin{array}{c}\text { Liquid } \\
\text { to solid } \\
\text { ratio } \\
(\mathrm{ml} / \mathrm{g})\end{array}$ & $\begin{array}{c}\text { Temperature } \\
\left({ }^{0} \mathrm{C}\right)\end{array}$ & $\begin{array}{l}\text { Duration } \\
\text { (h) }\end{array}$ & $\begin{array}{c}\text { Mixing } \\
\text { speed } \\
\text { (rpm) }\end{array}$ & $\begin{array}{l}\text { Extracted } \\
\text { phase }\end{array}$ \\
\hline Step 1 & $1 \mathrm{M} \mathrm{MgCl}_{2}$ & 7 & $20 / 1$ & 25 & 1 & 120 & Exchangeable \\
\hline $\begin{array}{l}\text { Step } 2 \\
\text { Step } 3\end{array}$ & $\begin{array}{l}1 \mathrm{M} \mathrm{CH}_{3} \mathrm{COONa} \\
0.04 \mathrm{M} \mathrm{NH}_{2} \mathrm{OH} . \mathrm{HCl}\end{array}$ & 5 & $20 / 1$ & 25 & 5 & 120 & Carbonates \\
\hline Step 4 & in $25 \%$ acetic acid & - & $\begin{array}{c}\text { 20/1 } \\
\text { Calcula }\end{array}$ & 50 & 5 & 120 & $\begin{array}{l}\text { Fe-Mn oxides } \\
\text { Residual }\end{array}$ \\
\hline
\end{tabular}

Table 5. Calculated saturation indices under oxic conditions for sample ST6-13

\begin{tabular}{|c|c|c|c|c|}
\hline & Leachate 1 & Leachate 2 & Leachate 3 & Leachate 4 \\
\hline \multicolumn{5}{|l|}{ Parameter } \\
\hline pH (measured) & 7.03 & 7.45 & 9.36 & 11.73 \\
\hline pe (calculated from Eh) & 7.54 & 6.98 & 5.16 & 3.72 \\
\hline \multicolumn{5}{|l|}{ Saturation indices: } \\
\hline Anglesite $\left(\mathrm{PbSO}_{4}\right)$ & -3.29 & -3.00 & -4.06 & -7.41 \\
\hline Cerrusite $\left(\mathrm{PbCO}_{3}\right)$ & -2.17 & -0.93 & 0.06 & -2.33 \\
\hline Hydrocerrusite $\left(\mathrm{Pb}\left(\mathrm{CO}_{3}\right)_{2} \mathrm{OH}_{2}\right)$ & -6.88 & -3.50 & 1.15 & -2.52 \\
\hline Goethite (FeOOH) & 6.79 & 7.46 & 7.13 & 4.97 \\
\hline $\mathrm{Fe}(\mathrm{OH})_{3}$ & 2.62 & 3.30 & 2.96 & 0.81 \\
\hline Hematite, alpha $\left(\mathrm{Fe}_{2} \mathrm{O}_{3}\right)$ & 13.09 & 14.4 & 13.77 & 9.45 \\
\hline $\mathrm{Pb}(\mathrm{OH})_{2}$ & -2.52 & -1.46 & 1.06 & 2.18 \\
\hline Magnetite, alpha $\left(\mathrm{Fe}_{3} \mathrm{O}_{4}\right)$ & 7.84 & 10.0 & 8.91 & 1.51 \\
\hline
\end{tabular}


Table 6. Chemical reactions and equilibrium constants at $25^{\circ} \mathrm{C}$ of calcite, $\mathrm{CaCO}_{3}, \mathrm{CaOH}^{+}$and $\mathrm{CaHCO}_{3}{ }^{+}$under oxic and reducing conditions using Geochemist's workbench ${ }^{\circledR} \mathrm{RXN}$ program

\begin{tabular}{|c|c|c|}
\hline Chemical reactions & $\begin{array}{l}\text { Additional chemical } \\
\text { species present }\end{array}$ & $\log K$ \\
\hline $\mathrm{Ca}_{(\mathrm{aq})}^{2+}+\mathrm{HCO}_{3}^{-}{ }_{(\mathrm{aq})}+\mathrm{OH}_{(\mathrm{aq})}^{-} \longleftrightarrow$ Calcite $_{(\mathrm{s})}+\mathrm{H}_{2} \mathrm{O}$ & - & 12.3 \\
\hline $\mathrm{Ca}^{2+}{ }_{(\mathrm{aq})}+\mathrm{HCO}_{3}^{-}{ }_{(\mathrm{aq})}+\mathrm{OH}_{(\mathrm{aq})}^{-} \longleftrightarrow \mathrm{CaCO}_{3(\mathrm{aq})}+\mathrm{H}_{2} \mathrm{O}$ & - & 6.86 \\
\hline $\mathrm{Ca}^{2+}{ }_{(\mathrm{aq})}+\mathrm{HCO}_{3(\text { (aq) }}^{-} \longleftrightarrow \mathrm{CaHCO}_{3}^{+}{ }_{(\mathrm{aq})}$ & $\mathrm{OH}^{-}$ & 1.22 \\
\hline $\mathrm{Ca}^{2+}{ }_{(\mathrm{aq})}+\mathrm{OH}_{(\mathrm{aq})}^{-} \longleftrightarrow \mathrm{CaOH}_{(\mathrm{aq})}^{+}$ & $\mathrm{HCO}_{3}^{-}$ & 1.30 \\
\hline $\mathrm{Ca}^{2+}{ }_{(\mathrm{aq})}+\mathrm{HCO}_{3}^{-}{ }_{(\mathrm{aq})}+0.5 \mathrm{~S}_{(\mathrm{aq})}^{2-} \longleftrightarrow$ Calcite $_{(\mathrm{s})}+0.5 \mathrm{H}_{2} \mathrm{~S}_{(\mathrm{g})}$ & $\mathrm{S}_{2} \mathrm{O}_{4}^{2-}$ & 9.23 \\
\hline $\mathrm{Ca}^{2+}{ }_{(\mathrm{aq})}+\mathrm{HCO}_{3 \text { (aq) }}^{-}+0.5 \mathrm{~S}^{2-}{ }_{(\mathrm{aq})} \longleftrightarrow \mathrm{CaCO}_{3(\mathrm{aq})}+0.5 \mathrm{H}_{2} \mathrm{~S}_{(\mathrm{g})}$ & $\mathrm{S}_{2} \mathrm{O}_{4}{ }^{2-}$ & 3.81 \\
\hline $\mathrm{Ca}^{2+}{ }_{(\mathrm{aq})}+\mathrm{HCO}_{3(\mathrm{aq})}^{-} \longleftrightarrow \mathrm{CaHCO}_{3}^{+}{ }_{(\mathrm{aq})}$ & $\mathrm{S}_{2} \mathrm{O}_{4}{ }^{2-}, \mathrm{S}^{2-}, \mathrm{H}_{2} \mathrm{~S}_{(\mathrm{g})}$ & 1.22 \\
\hline $\mathrm{Ca}^{2+}{ }_{(\mathrm{aq})}+\mathrm{H}_{2} \mathrm{O}+0.5 \mathrm{~S}^{2-}{ }_{(\mathrm{aq})} \longleftrightarrow \mathrm{CaOH}_{(\mathrm{aq})}^{+}+0.5 \mathrm{H}_{2} \mathrm{~S}_{(\mathrm{g})}$ & $\mathrm{S}_{2} \mathrm{O}_{4}^{2-}, \mathrm{HCO}_{3}^{-}$ & -1.75 \\
\hline
\end{tabular}

Table 7. Calculated saturation indices under reducing conditions for sample ST6-13

\begin{tabular}{lccc}
\hline & Leachate 1 & Leachate 2 & Leachate 3 \\
\hline Parameter & & & \\
pH (measured) & 4.89 & 7.58 & 12.6 \\
pe (calculated from Eh) & -3.79 & -8.03 & -10.97 \\
& & & \\
Saturation indices: & & & \\
Goethite (FeOOH) & -5.61 & -3.38 & 2.38 \\
Hematite, alpha $\left(\mathrm{Fe}_{2} \mathrm{O}_{3}\right)$ & -11.7 & -7.26 & 4.28 \\
Hematite, beta $\left(\mathrm{Fe}_{2} \mathrm{O}_{3}\right)$ & -0.88 & 3.57 & 15.1 \\
$\mathrm{Hematite,} \mathrm{gamma}\left(\mathrm{Fe}_{2} \mathrm{O}_{3}\right)$ & 8.70 & 13.2 & 24.7 \\
$\mathrm{Lepidocrocite}(\mathrm{FeOOH})$ & -6.64 & -4.41 & 1.36 \\
$\mathrm{Fe}(\mathrm{OH})_{2}$ & -6.74 & -2.96 & 0.76 \\
$\mathrm{Fe}(\mathrm{OH})_{3}$ & -9.78 & -7.55 & -1.79 \\
$\mathrm{~Pb}$ & -4.13 & 3.58 & 1.01 \\
$\mathrm{~Pb}(\mathrm{OH})_{2}$ & -5.83 & -1.23 & 0.30 \\
\hline
\end{tabular}


Table 8. The pe $+\mathrm{pH}$ parameter measured under reducing conditions

\begin{tabular}{cccccc}
\hline Sample & $\mathrm{pH}$ & $\begin{array}{c}\mathrm{pe}+\mathrm{pH} \\
\text { parameter }\end{array}$ & Sample & $\mathrm{pH}$ & $\begin{array}{c}\text { pe }+\mathrm{pH} \\
\text { parameter }\end{array}$ \\
\hline \multirow{5}{*}{ ST6-3 } & 6.28 & 0.2 & & 5.24 & 0.4 \\
& 6.09 & 0.2 & 4.2 & 0.4 \\
& 6.72 & -0.2 & ST6'-5 & 6.29 & 0.0 \\
& 7.46 & -0.6 & 7 & 0.0 \\
& 7.82 & -0.5 & & 7.73 & -0.6 \\
ST6-13 & 12.7 & 2.4 & & 12.44 & 1.9 \\
& 4.07 & 6.8 & & 3.72 & 0.9 \\
& 4.89 & 1.1 & 4.9 & 0.8 \\
& 7.1 & 0.4 & ST6-14 & 6.22 & 0.1 \\
& 7.58 & -0.1 & & 6.95 & -0.1 \\
& 12.57 & -0.4 & & 8.37 & -0.7 \\
\hline
\end{tabular}

